\title{
Generational and Gender Differences in Sexual Life in St. Petersburg and Urban Finland
}

\author{
ELINA HAAVIO-MANNILA \\ Professor \\ Department of Sociology \\ University of Helsinki \\ Helsinki, Finland
}

\section{ANNA ROTKIRCH \\ Lecturer \\ Department of Social Policy \\ University of Helsinki \\ Helsinki, Finland}

\begin{abstract}
This article is to our knowledge the first empirical comparison of sexual behavior in Eastern and Western Europe. The timing of some sexual life events, sexual behavior patterns, and sexual satisfaction will be compared on the basis of survey data and sexual autobiographies from urban Finland and St. Petersburg (former Leningrad) in Russia. We were interested in the impact of the so-called sexual revolution taking place in public life in different decades - in Western Europe and Finland in the 1960s, in Russia in the late 1980s. We assumed that this difference would appear as country differences in "traditional" vs. "liberated" sexual behavior, and especially in the sexual satisfaction of women. This hypothesis proved generally to be true, but with several important modifications. The sexual behavior and attitudes in St. Petersburg are shown to have liberalized about 15 years later than in Finnish towns. While the sexual behavior of men and women has become almost similar in Finland, the trend towards equalization of sexual life is not as clear in Russia. Divorce and parallel relationships are more common in Russia, while the number of sexual partners and overall sexual satisfaction is higher in Finland.

Country, gender, and generation are the main independent variables of the statistical elaborations. The biographical material is used for exemplifying and interpretative purposes.
\end{abstract}

Keywords: sexual behavior, comparison, Finland, St. Petersburg, Eastern Europe, Western Europe

\section{Research hypothesis and cultural context}

Previous research on the sexual life of Finns has found clear differences between three groups, which are called "sexual generations": the generation of sexual repression (born in 1917-1936), sexual revolution (1936-1956), and ambivalence or gender equality (1957-1973) (Kontula and Haavio-Mannila 1995b; Haavio-Mannila et al. 1996). The changes in sexual life in Finland have followed two main trends:

(1) A shift from "traditional" to "liberalized", or more permissive, attitudes and behavior 
in sexual life. Traditional European societies regulated sexual behavior by clear norms, the aim of which was to enforce the status of heterosexual marriage and to control women's reproductive behavior. A liberalization of these norms entailed the spread and approval of earlier and plural sexual practices, the separation of sexuality from reproduction and the image of sexually active women, a public ideology of sexual enlightenment, and the liberalization of sexual words and images in the media. In Finland, liberalization begins with the middle generation that grew up in the 1960 s and is called the generation of the sexual revolution. In sexual practices, liberalization is accompanied, for example, by an earlier onset of sexual life, a higher number of marriages and sexual partners, more varying kinds of sexual techniques, and higher level of sexual satisfaction, especially for women. (Kontula and Haavio-Mannila 1995a; Haavio-Mannila 1997)

(2) The behavior and values of men and women grow more similar. This change in the gendered sexual scripts (Francoeur 1990) entails a narrowing of the gender gap and an equalisation of sexual behaviour and norms. In Finland, the gender gap in sexual life has almost disappeared in the youngest generation. Girls have started to behave more like boys (for example, by having more sexual partners). In the youngest generation, boys have also changed their behavior (for example, young men start cohabiting at the same age as young women). The youngest generation of equality is also called the generation of ambivalence, because although practice remains liberal, some of the values of Finnish young people are again more traditional, emphasizing ideals such as life-long fidelity (Haavio-Mannila et al. 1996). ${ }^{1}$

The Finnish experience is one example of the general development in Western Europe. Our general research question was: In what ways does the material from St. Petersburg give evidence to similar trends: traditionalism/liberalization and gender polarity/equalization?

Predictably, the biographical material from St. Petersburg did not show the same generational dividing lines as in Finland (Rotkirch 1997). The main reasons for this lie in the general level of material well-being and the Soviet policy on reproductive and sexual issues. Notably, the postwar Soviet Union still had a huge housing shortage, with the majority of urban working families in the big cities living in one room only (Semyonova 1996,374). As one of the biographical authors put it: "Practically all our private life took place before the eyes of our relatives" (Woman, born 1937). The shortage of space for intimate life was and still remains a major factor.

Second, the Soviet Union did not have a public discussion about sexuality similar to that of the 1960 s in the West. In the Nordic countries, what begun as a debate on young people's sexuality grew into a critique of sexual taboos and sex roles. This is now called the "sexual revolution". In the Finnish context, which is our reference, this meant

(a) a public discussion combined with a liberalization of the press

(b) an ideology of sex enlightenment propagated through institutions such as the school and the health care system, together with the spread of modern contraceptives, especially the pill, and

c) the connected changes in sex roles: the development of an economically and socially independent woman by the so-called gender contract of the "wage working mother". (Kontula and Kosonen 1994; Lennerhed 1994; Rantalaiho 1994).

In the Soviet Union, the economic aspects of women's liberation had mainly taken place already in the 1930s (Liljeström 1995). With regards to aspects (a) and (b) of the sexual revolution, the postwar period introduced only minor changes in the sexual policy of the Communist regime. The main policy remained traditional: to enforce heterosexual monogamous family life and motherhood (Liljeström 1995). Up until the 1980s sexual education and research on sexuality had to be very limited in scope, while small amounts of information and moral advice featured in medical and pedagogical journals. All other public discussion of so-called intimate questions was censored. The Gorbachev policy of glasnost eventually led to the liberalization

\footnotetext{
1 "Traditional" and "liberal" are thus defined in relationship to each other, without any implied moral scale. Research has shown that what we call a liberal or permissive sexual culture increases sexual health and satisfaction, but this does, of course, not mean that we would automatically endorse all phenomena of "liberalization".
} 
of the printed word and a Russian public "sexual revolution" in 1989, when topics such as abortions, birth clinics, contraceptives, and young people's sexuality entered public debate (Kon 1995, 267).

Notwithstanding Communist censorship, the actual sexual behavior of Soviet people in many ways followed the development of other industrialized countries in the postwar era. The similarities included earlier onset of sexual life and more permissive attitudes towards extramarital affairs and divorces (Kon 1995; Haavio-Mannila et al. 1996). This had to do with the improving living standards of the 1960 s - the growing number of family apartments and living space, as well as more time for leisure activities and travel.

Urbanization and modernization thus led to similar trends in sexual behavior in Western and Eastern Europe. Still, there were some features of Finnish sex life that we supposed could be attributed more precisely to the sexual revolution with its public debates and wider distribution of information, pornography, and literature about sex. Women's sexual activity and satisfaction especially was a "new" topic of the Western 1960s. Although it was at that time often defined by men and exploited commercially, it nevertheless evolved into a cultural model for many women. "The pop ideology of the sexual liberation was that (...) women enjoyed sex as much as men, and in the same way as men were imagined to enjoy it - that is, actively, promiscuously, and without guilt." (Menand 1997, 27) This kind of feminine sexuality is not uncommon in the generation of Finns growing up in the 1970s. Kontula and Kosonen $(1994,297)$ conclude that the lively discussion about sexuality and gender issues in the Finnish media since the beginning of the 1960s has significantly contributed to the increase in women's sexual satisfaction after the 1970s and to the nowadays better matched sexual expectations between men and women in Finland.

Our second research question was therefore about the possible Finnish-Russian cross-cultural differences particularly in women's sexual experiences.

\section{Research themes and materials}

The following aspects of sexual life patterns in St. Petersburg and Finnish towns and cities will be examined in this article:

(1) Sexual initiation or the timing of sexual events during the life course: age at first dating, intercourse and marriage or cohabitation. In post-traditional European societies, the tendency is for all these events to happen at an increasingly earlier age. The answers can thus be taken as indicators of "traditional" or "liberated" sexual behavior.

(2) Sexual practices: frequency of intercourse, the use of other than man-on-top positions in intercourse, and practicing oral sex. These factors have proved to be related to overall sexual satisfaction. Different positions and oral sex are also disapproved of or prohibited in the religious teachings and social values of traditional European societies.

(3) Sexual partners: consecutive sexual relationships (i.e., the number of marital or cohabiting relationships), complementary relationships (i.e., attitudes towards infidelity and parallel sexual relations), and the quantity (number) of sexual partners during one's lifetime. These are patterns of sexual behavior that vary according to generation and gender in Finland.

(4) Sexual satisfaction: overall satisfaction, finding intercourse pleasurable, achieving orgasm, and wishing to have intercourse more often. The development in Finland has been towards greater sexual satisfaction, especially for women.

Any comparison between Finland and St. Petersburg touches upon several contextual factors, only some of which we are able to take into account here. The first one is size. Our initial data comes from two very different settings: a small nation and the second largest city of one of the biggest countries in the world. In order to make the comparison more feasible, we have chosen from the first nationwide Finnish survey only the data from towns with more than 20,000 inhabitants (which did not significantly alter the Finnish outcome). As a city, St. Petersburg is a metropolis and some of the Finnish towns are quite small. One should take this into consideration when interpreting the results. 
Although we for the sake of simplicity talk about "country differences" and sometimes of "Russian" vs. "Finnish" characteristics, the reader should be reminded that one cannot equate St. Petersburg with Russia or even with Russian urban culture. St. Petersburg has its specific cultural, industrial, and demographic aspects. The city is known as Russia's window to Europe, where moral values, for example, can be expected to be more liberal than in other parts of Russia.

St. Petersburg and Finnish cities differ in religion (Greek Orthodox and Protestant, respectively), language, ethnicities, and economic and judicial systems. But they are close in what concerns geography, climate, and a shared 19 th century history. The majority is secularized in both cultures. The majority is also highly educated - in St. Petersburg three quarters and in Finnish cities about half of the population have higher or secondary education (St. Petersburg Helsinki - Turku in Figures 1997, 59).

This article is based on personal interviews and self-completed questionnaires of representative samples of people aged 18-74 years in St. Petersburg in $1996(\mathrm{~N}=2,081)$ and in Finnish cities and towns with over 20,000 inhabitants in $1992(\mathrm{~N}=1,117)$. In addition, 926 people aged 18-54 interviewed in urban Finland in 1971 are included in the study. The response rate in St. Petersburg was 60 percent and in Finland 91 percent in 1971 and 76 percent in 1992 (see Gronow et al. 1997; Kontula and Haavio-Mannila 1995a; 1997b; Sievers et al. 1974). The St. Petersburg and the Finnish studies resemble the nationally representative surveys conducted in the 1990s in the USA, the United Kingdom, and Sweden (Laumann et al. 1994; Wellings et al. 1994; Lewin 1997). The high response rate in the Finnish study in 1971 is related to the fact that the interviews were carried out by local public health nurses, who seem to have been better in persuading people to participate than the professional interviewers of Statistics Finland, who conducted the study in 1992. Kontula and Haavio-Mannila (1993) have compared the responses to the same questions (for example, age at first intercourse) by age cohorts and found out that they resemble each other very well. Thus the lower response rate of the later study probably has not had a great impact on the results relating to sexual life. The lowest response rate was in St. Petersburg. Nevertheless, the sample is quite representative of the population as regards gender and age. One can here mention that in the large and expensive Swedish sex survey of 1996 (Lewin 1997), the response rate was the same as in our study in St.Petersburg.

The gender and age distribution of the samples is presented in Table 1. The average age of the respondents in St. Petersburg is 41.2 years for men (standard deviation 14.8) and 43.0 years for women (15.0). In Finland in 1992, the respective figures are 40.1 for men (14.2) and 42.0 for women (15.6). The age structures are thus almost identical.

Table 1. Generation, age, and birth cohort of the interviewees in St. Petersburg in 1996 and Finnish Cities in 1992 and 1971.

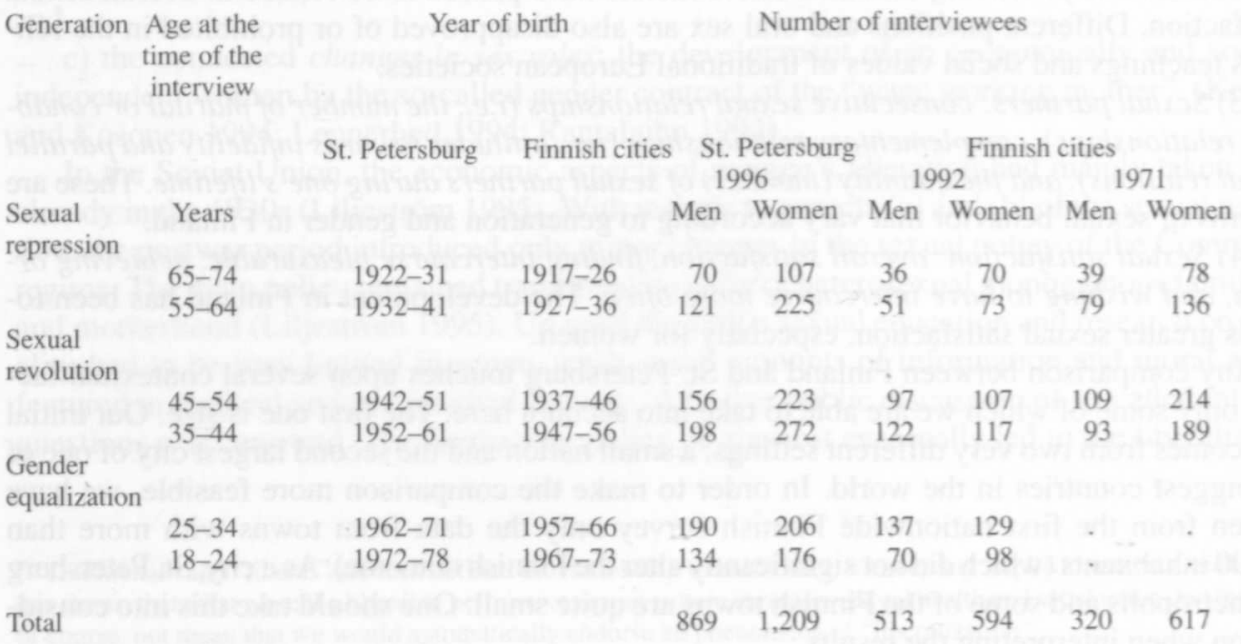


Table 2. Marital status and education of men and women in St. Petersburg in 1996 and in Finnish cities 1992.

\begin{tabular}{|c|c|c|c|c|}
\hline \multirow[t]{2}{*}{ Marital status } & \multicolumn{2}{|c|}{ St. Petersburg } & \multicolumn{2}{|c|}{ Urban Finland } \\
\hline & Men $\%$ & Women \% & Men \% & Women \% \\
\hline Never married or cohabiting & 19 & 14 & 21 & 22 \\
\hline Cohabiting & 7 & 6 & 17 & 14 \\
\hline Married & 62 & 52 & 55 & 47 \\
\hline Divorced & 9 & 16 & 6 & 9 \\
\hline Widowed & 3 & 12 & 1 & 8 \\
\hline $\begin{array}{r}\% \\
(\mathrm{~N})\end{array}$ & $\begin{array}{c}100 \\
(867)\end{array}$ & $\begin{array}{r}100 \\
(1,207)\end{array}$ & $\begin{array}{c}100 \\
(511)\end{array}$ & $\begin{array}{c}100 \\
(593)\end{array}$ \\
\hline
\end{tabular}

Education

No vocational course or higher general education

F: Only comprehensive school or matriculation examination

9

30

vocational education

F: College

P: University education,

uncompleted included

F: University

$$
\%
$$

34
100
$(868)$

$(1,207)$
16

40

9
100
$593)$

$\mathrm{P}=$ St. Petersburg

$\mathrm{F}=$ Finland

There are more married, divorced, and widowed respondents in St. Petersburg, whereas there are more single and cohabiting people in Finland (Table 2). Even though the categories of education are not easily comparable, the educational level seems to be higher in St. Petersburg than in Finnish cities.

In the different sections of the article, we look at the survey data on sexual life according to country, gender and generation. In some cases we also use education as an indicator of social class. For each question, we looked at the gender and country differences - "gaps" - in sexual patterns. The relative importance of the country and gender differences is studied by analyses of variance, in which cohort is controlled. The two oldest cohorts belong to the Finnish generation of sexual repression, the two middle cohorts to that of sexual revolution and the two youngest cohorts to that of sexual ambivalence or gender equalization. We speak of these generations as the "old", "middle" and "young" generations.

We also use autobiographies about love and sexuality collected in a writing contest in Finland in $1992(\mathrm{~N}=166)$ and one in St. Petersburg in $1996(\mathrm{~N}=45)$ (see Kontula and HaavioMannila 1995b; Rotkirch 1997; Rotkirch and Haavio-Mannila 1997). In autobiographies, people describe social processes and events which have taken place during their life course, the prevailing sexual scripts, and other factors that have shaped their sexual life style. For this article, several themes of statistical research were first formulated after comparisons between Finnish and Russian autobiographies. In the text, we use the biographical material both to exemplify or illustrate and to interpret the statistical results (Bertaux 1997, 46-50). 
We will here selectively use three biographies from St. Petersburg and three from Finland. The first Russian biography is by Maria, a nursery school teacher born in 1946, "almost three times married" as she puts it (twice in registered marriages and once cohabiting) and three times divorced, with two children. The second is by a man who wants to use the pseudonym " $\mathrm{K}$. Mjagkolapov" (K. Softhands), who was born in 1944 and is a technician living with his wife and two children. The third is by Elza, born in 1954, school teacher and housewife, married, and with three children.

Leena is a Finnish woman, born in 1946, whose both parents were workers while she herself became a musician. Leena is divorced with one adult child. Jyrki, born in 1948, came from poor agrarian conditions and became a chef. He had one child as a young man and is now living with his third wife. Finally, Ritva was born in 1953. She begins her biography stating how "I married the tenth [partner] and am now living happily as a mother of two sons together with my husband."

The biographies were chosen in order to represent two life stories from the postwar "baby boomers" generation in each country (Maria and Softhands, Leena and Jyrki). This was in Finland the first cohort of the generation of sexual revolution. The third biography from each country is of a woman born one decade later. Among the Finnish women, Leena and Ritva were chosen because they represent clear examples of a generational consciousness: they often and explicitly refer to their sexual life as typical of the times (the 1960s and the 1970s, respectively). We have not found similar references to sexual generations in the St. Petersburg biographies, although the authors, of course, do refer to what is "customary" at a certain time or in certain circles. The Russian women (Maria and Elza) were instead chosen merely as exemplarily "thick" biographies, describing the essential changes of their times. The Finnish man, Jyrki, was chosen as an example from an agrarian and working milieu, which is otherwise underrepresented in our biographies. The Russian man, "Softhands", is a quite typical male biographer of his generation.

\section{The age of sexual initiation}

\section{First dating and intercourse}

In both Finland and St. Petersburg, the age of dating and sexual initiation has been steadily decreasing. People in St. Petersburg have dated for the first time and had their first sexual intercourse later than those in Finland (Table 3, F-value indicating the strength of the country difference, when the influence of gender and cohort is controlled, is for age of first dating $170.6^{* * *}$ and of first intercourse $\left.89.2^{* * *}\right)$. The average ages for these events are in today's St. Petersburg about the same as they were in Finland some fifteen years ago.

In both countries, women and men have started to date at approximately the same age (Figure 1). The only exception is that in St. Petersburg there is a small gender gap in the middle generation, born in 1942-1961, in which women have begun to go steady at a little older age than men. 
Table 3. Means of the characteristics of sexual life presented in Figures 1-10.

Characteristics

1. Age at first dating, years

$\mathrm{F}=$

Country $170.6^{* * * *}$

Gender $10.2 * * *$

Cohort $71.5 * * *$

2. Age at first intercourse, years

$\mathrm{F}=$

Country $89.2 * * *$

Gender 100.3***

Cohort 90.3***

3. Age at first marriage or cohabitation, years

$\mathrm{F}=$

Country $6.1 * * *$

Gender 106.6***

Cohort $60.0^{* * * *}$

4. Traditional towards premarital sex, means, range $1-5$

$\mathrm{F}=$

Country $72.2^{* * * *}$

Gender 56.4***

Cohort 97.1***

5 . Several marriages or cohabitations, $\%$

of total sample

20

18

Country $5.5^{*}$

Gender $0.5 \mathrm{~ns}$

Cohort 20.0***

6. Acceptance of a husband's infidelity, means, range $1-5$

$\mathrm{F}=$

Country $71.1 * * *$

Gender 139.1****

Cohort $1.9 \mathrm{~ns}$

7. Parallel sexual relations, $\%$ of cohabiting persons

$\mathrm{F}=$

Country $20.6^{* * *}$

Gender 185.3***

Cohort $6.4 * * *$

8. Median number of sexual partners

during lifetime

$\mathrm{F}={ }^{2)}$

Country $16.7^{* * * *}$

Gender 107.2***

Cohort $3.7^{* *}$

9. Satisfaction with sexual life,

means, range $1-5$

Country $179.2 * * *$

Gender 24.8***

Cohort $6.5 * * *$

10. Prefers more frequent intercourse,

$\%$ of persons having a steady relationship 45

34

$\mathrm{F}=$

Country ns

Gender 58.9***

Cohort $6.3 * * *$

1) The statistical significance of country, gender, and cohort differences is examined by analysis of variance (ANOVA) in which the influence of the other independent variables is controlled. F-values and their significance:

*** $\mathrm{P}<.001, * * \mathrm{P}<.01$, and * $\mathrm{P}<.05$.

${ }^{2} \mathrm{~F}$-values are calculated on the basis of mean numbers of partners. 
Figure 1. Age at first steady dating.

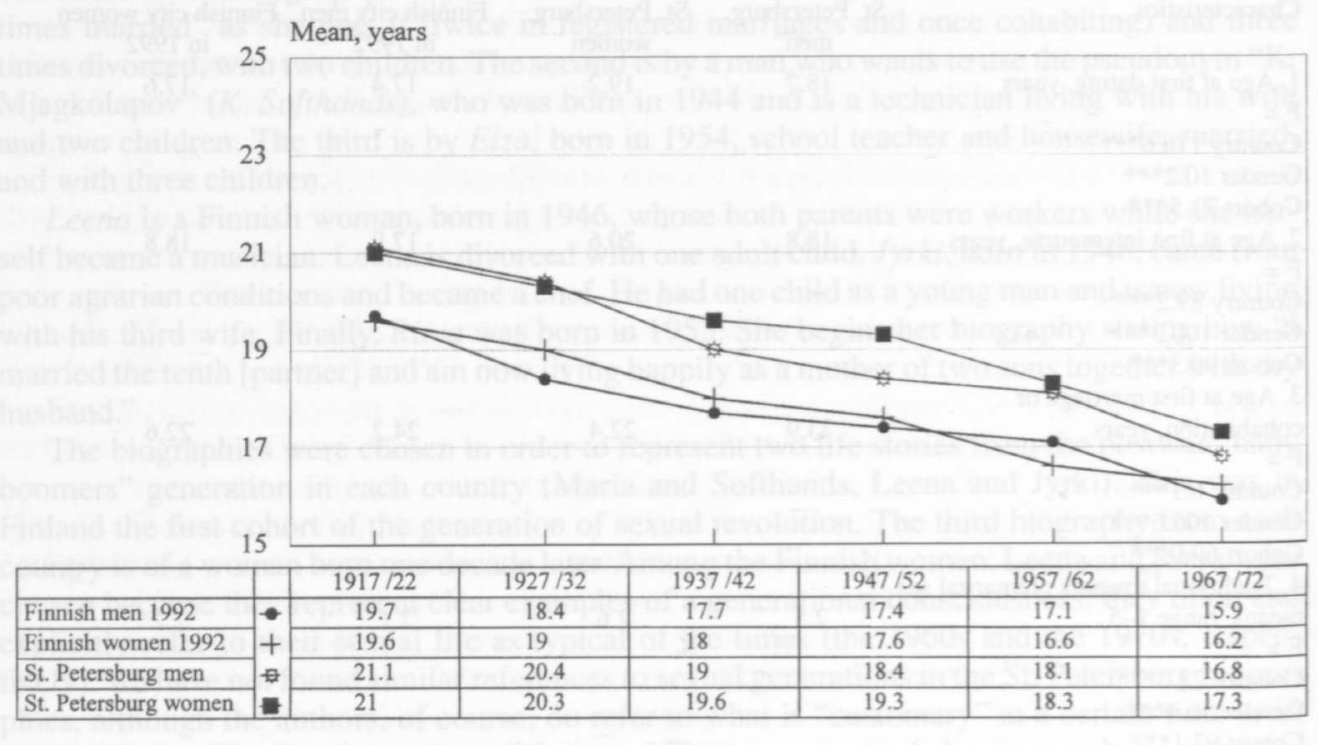

Starting year of birth decade (Finnish cities/St. Petersburg)

St. Petersburg respondents have had their first sexual intercourse one or two years older than Finns (Figure 2). The country gap in the age of starting intercourse is larger among women than among men. Men had their first coitus in St. Petersburg on the average at the age of 18.8 (standard deviation 3.9) years and in Finnish cities at 18.1 (3.2) years of age, while women in St. Petersburg were on average 20.6 (3.8) years and in Finland 18.7 (3.5) years old. Finnish women and St. Petersburg men resemble in this respect each other in all birth cohorts.

Figure 2. Age at first sexual intercourse.

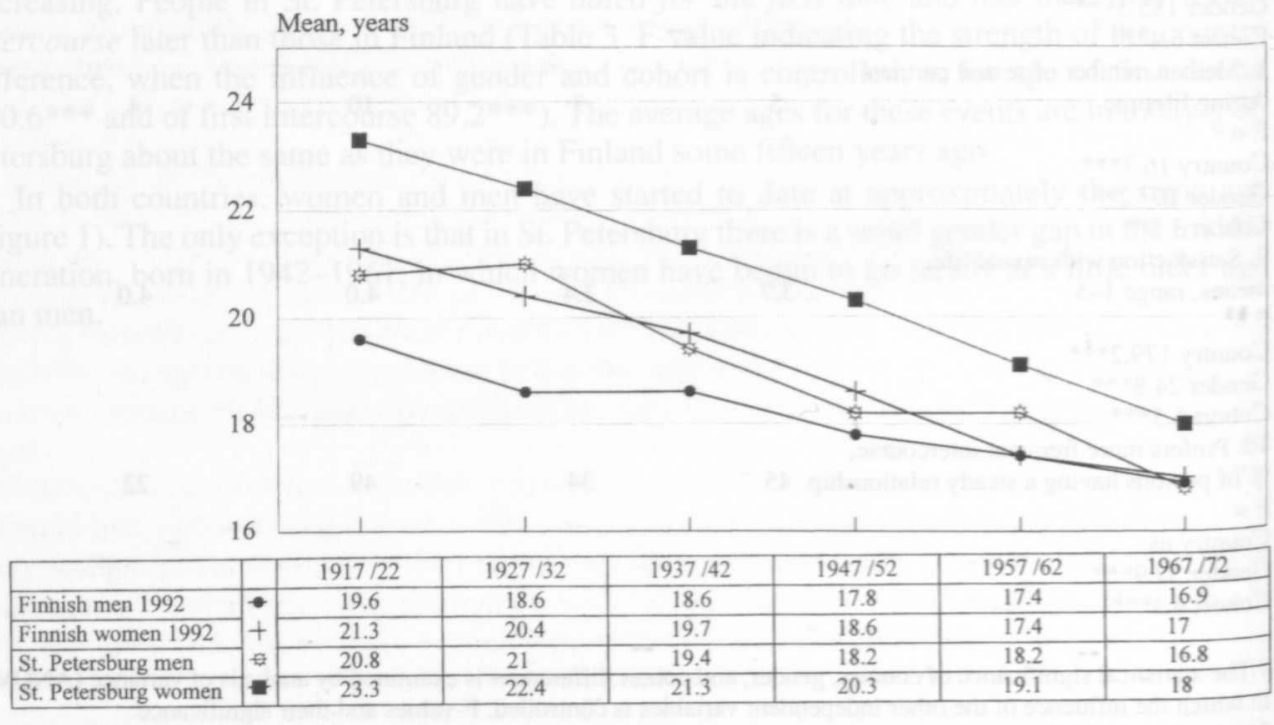


The gender gap (men starting intercourse at an earlier age than women) is bigger in St. Petersburg than in Finland, and in both countries it is much larger in the older generations. In St. Petersburg, men from the older and middle generations have had their first intercourse about two years earlier than women, and in the younger generation one year earlier. In Finland, men of the older generation have started intercourse two years younger than women and in the middle generation one year younger. In the youngest Finnish generation there is no gender gap in the age at first intercourse, whereas the gender differences for the youngest age cohort in Russia still can be seen.

Maria (born in Leningrad in 1946) introduces herself as a blond and attractive woman. Due to her big and beautiful breasts, "whatever was the street fashion, I was never out of fashion". She spent the summer holidays at her grandmother's place in the countryside. Here she had her first love affair.

"The first kiss shook me. I was hysterical, as if I had lost my virginity. (...) But we didn't go any further than ecstatic caressing. I think the boy was sensible enough. I was 17 years old."

Three years later Maria "became a woman" with a man she was very much in love with:

"But except for a great pain and heavy bleeding (2 days), I don't remember anything. No, there was also a feeling of happiness because I had given my beloved something very precious. We parted in the classical way: he condemned me for being willing and left me."

Leena was born in 1943, and like Maria is 17 years when she kisses for the first time. She thinks this is late in life, "and he was not even important to me. I just had to try, as all others were 'smacking'." At 20, she has still not found anyone she is really interested in and can trust. "All my girlfriends had already tried 'it', and in the end I also began to feel that I was completely behind the times."

At 21 she falls in love with another musician and goes to bed with him.

"The famous first time was a rather stupefying experience, in theory I knew everything but reality was of course something else. But L. was reliable, cute and in fact a very passionate guy. Gradually we learned more, and the mental pressure was relieved some weeks after the 'first time', when my more experienced girlfriends told me about a doctor, who prescribed pills to girls who were engaged."

Leena's sexual education at home had been traditional, restricted to her mother saying "Listen Leena, I do think those things are quite overvalued", and her father: "It's no use coming to this household with a bastard on your arm. You'd both be thrown out." But the times are clearly beginning to change, and when using a fake engagement ring she obtains contraceptive pills, which were generally not yet prescribed to unmarried women, she feels free of her father's sinister warnings.

The pseudonym Softhands (born 1944) had one great love during his childhood and youth. This girl died in a tragic accident, but he still remembers her birthday every year with flowers. His first sexual experience is at age 19. A work colleague and friend "calmly and openly" said that she would personally take care of making a man out of him. This woman had recently married and has a small child. They meet at her place, she provides him with condoms, and it is a very pleasurable happening.

"Later we still met for many years at work and there was never even any hint at what had once taken place. Probably I wasn't that upset after my first close contact with a woman because I knew everything theoretically and was morally ready. The kind and tender attitude of my first partner also played a significant role."

Similar situations without worse feelings are present in several male biographies, while no women of this generation describe such a sweet and undramatic first time with someone they are not dating.

The Finnish man, Jyrki (born 1948), grows up in a large family in a poor agrarian milieu, which is sexually unrestricted - from his early childhood he plays daring sexual games with other kids. He is 15 when he has sexual intercourse for the first time, a strong and good experience in a shed with several other young experimenting couples. He has several shorter affairs. But when he at 16 meets his future wife, he considers her too young for sex. A couple of years later the situation is different, and they start having sex, not caring about contraceptives.

Elza (born in 1954 in Leningrad) has her first boyfriend at the age of fifteen. Then she 
"takes over" a boy her girlfriend has got tired of. They engage in petting but no intercourse. Later she learns from her girlfriends about the meaning of virginity. She understands that she has broken her hymen herself masturbating as a young girl. As she has "nothing to lose" - she thinks any man will see that she is "dirty and perverse" - she decides to have sex with a man for the first time at 18 , during a trip to the Black Sea. But she also notes how "at those times virginity was not [yet] a disadvantage, and it was somehow customary to guard it, at least in my circles."

Ritva from Finland (born in1953) describes herself in the following way:

"I am a child of the 1970s, I turned 20 in 1973. The period was greatly influenced by the sexual liberation of the $60 \mathrm{~s}$ and chastity was really old-fashioned. Cohabitation and open relationships were new concepts and fashionable in Finland, and were often misunderstood to mean infidelity both in marriages and cohabiting relationships. (...) gradually I learned what kind of relationship I wanted and did not want. For me it is clear that I also will do the choosing and decide myself what I want concerning the sexual as well as other aspects of life. I think I belong to the first generation of women who really know how to say no. (...) My generation, which began sexual life when the pill entered the market, have received a gift that older women could not even dream about."

Maria is 17 when she travels abroad and meets her first big love, whom she also has sex with.

"I remember thinking that if this is sin, then please God forgive me this one time. (...) I remember like it was yesterday how confounded but happy I felt. I remember how I thought as I went to the shower that I had somehow become more complete. I knew I had done the right thing. (...) But due to the lack of adequate contraceptives I was always afraid of becoming pregnant."

Also Ritva goes to a doctor to get pills, but the doctor refuses to give them to her. She eventually gets pregnant but has an abortion, without consulting her boyfriend.

As the Figures 1 and 2 show, the gender gaps among St. Petersburg inhabitants of the older and middle generations resemble those of the Finns of the older generation in the age of sexual initiation. Gender equalization began in this respect some twenty or thirty years later in St. Petersburg than in Finland. The largest country difference is in the middle generation, in which gender roles in St. Petersburg are more traditional than in Finland. The biographical quotes support this pattern: although Leena has intercourse at 21 and Maria at 20, Leena's is considered late and Maria's normal. Jyrki may be considered exceptionally early for his generation, but he nevertheless thinks 16 is too early for his girlfriend. Elza's debute at 18 is considered early, while Ritva's at 17 is normal for her - although the older generation (parents, doctors) disapprove of her sexual activity.

The statistical differences between St. Petersburg men and women in dating and having intercourse point to the same kind of double sexual standards as those prevailing in the West until the sixties. According to the traditional sexual scripts men started sexual intercourse relatively early with prostitutes or other "loose", often older women, whereas women should retain their virginity until marriage. Softhands' initiation resembles this pattern. Maria's remark about her first sexual partner tells about the moral standards of her time - she thinks the man left her because they had made love. Later, Maria comments again on the double standards of men:

"[When we got married] my husband already had quite a lot of sexual experience, but he did not use it with me. In Russia it is somehow not customary to do in bed with your wife the same things that you do with other women. This is perhaps the biggest mistake of our men, because the wives get that from other men and naturally begin to like them more."

There are plenty of examples of preserving virginity in the sexual autobiographies of Finnish women from the older generation and St. Petersburg women from the older and middle generation. In Finland, this part of the sexual script has clearly changed in the early 1970s, whereas Elza's story describes the preserved great value of virginity. The longer emphasis on women's chastity is also related to the poor contraceptive knowledge and means which made women fearful of unwanted pregnancy. In Finland, pills were available even if doctors were reluctant to prescribe them to young or unmarried women. As Leena exclaims: "Long live the pill and the IUD, the only real cornerstones of women's liberation!" This situation didn't arrive 
in Russia until at the end of the 1980s, when information and contraceptives became more available. Even in the youngest Russian generation, women gave examples of this, like in this quote from a librarian, born in Leningrad in 1964: "I had [when I was 21 years old] an ideé fixe to get married as a virgin, I was as afraid of pregnancy as I was of fire, of children born outside of marriage and such things. I had only diffuse ideas about the methods of birth control (...)".

\section{First marriage or cohabitation}

In contrast to the finding that St. Petersburg citizens start sexual life at a later age than Finns, there is no statistically significant country difference in the age of first marriage or cohabitation (Figure 3). Even though women start engaging in sexual intercourse at a more advanced age than men do, men settle down into marriage or cohabitation later than women do ( $\mathrm{F}$ for gender gap is $106.6^{* * *}$ ). Gender differences in age at first marriage or cohabitation are similar in Finnish cities and St. Petersburg. Again, the gender gap has disappeared in the youngest Finnish generation, so that the average age for Finnish men for the first time drops below that of Russian men.

Figure 3. Age at first marriage or cohabitation.

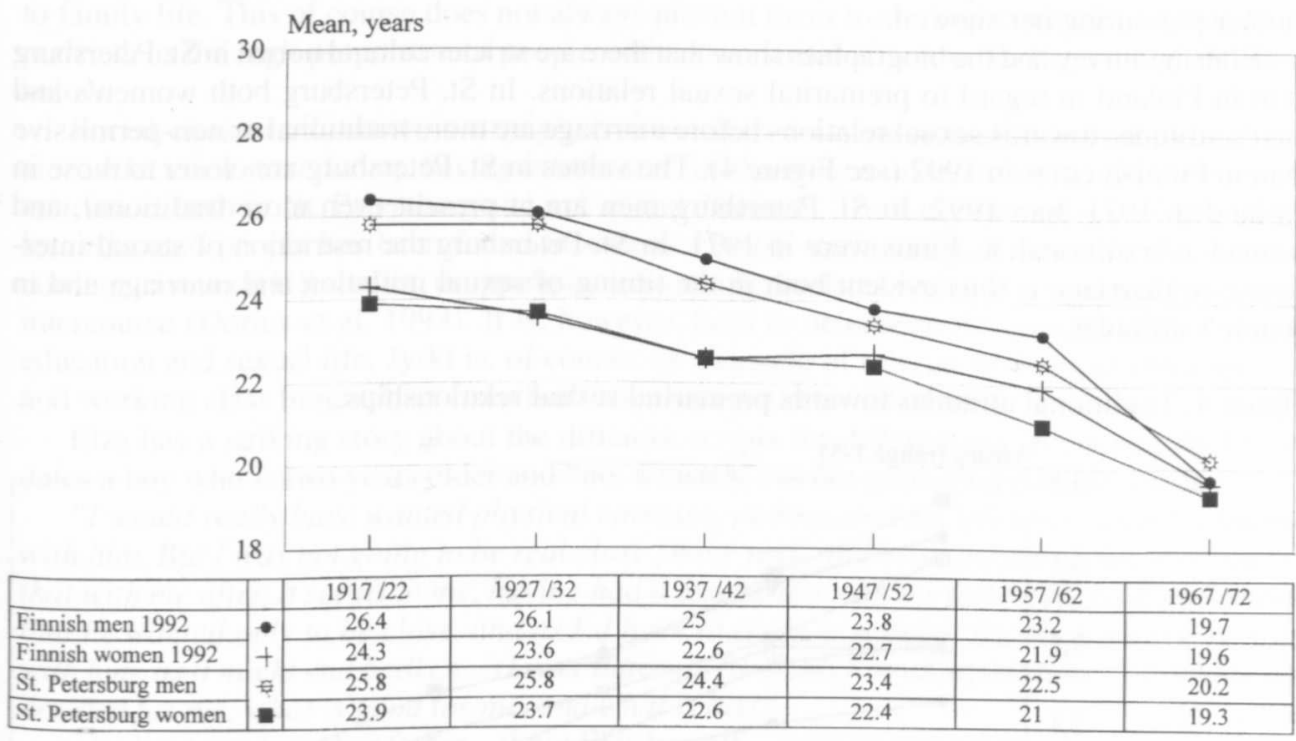

Starting year of birth decade (Finnish cities/St. Petersburg)

A comparison between the ages at first intercourse and marriage shows that for St. Petersburg men from the older and middle generations, the time between first intercourse and marriage is about five years. For the youngest generation of St. Petersburg men it is about four years. St. Petersburg women marry one or two years after their first sexual intercourse. In Finland, the interval between first intercourse and marriage is six or seven years for men, except in the youngest birth cohort where it is only three years. For Finnish women of all generations this difference is three to four years.

Maria married at 22 years of age. Her husband had been in love with her for several years, but she says she did not love him, she just wanted to get married: "I wanted to have a family, a home, I very much wanted a daughter, a small blond little daughter." 
Leena, by contrast, marries her first love because of lingering convention:

"I was at least not so liberated that I would have even considered any other alternative [than marriage], as he was my first. (At the time we got married, we were both studying and we had in the spirit of the times already gone to bed with many others. Oh sweet 60s, its free atmosphere and no threat of AIDS!) But a stable relationship still led to marriage in practically all cases, and also in ours, and at a young age. I was 23 and my husband 21 when we were married, and before that we had been dating already for almost three years."

Softhands was in the army and then the navy during most of the 1960s. He has one big love and several love affairs, but eventually ends up marrying a colleague when he is 31 years old. Jyrki's girlfriend becomes pregnant and they marry when he is only 17 , but divorce after a couple of years.

Elza also marries in the early 1970 s, at the age of 20 . She agrees to turn a sexual passion into official marriage because of pressure from her mother.

"My mother got to know about our relationship and set an ultimatum: either you register your marriage, or you part. I was very dependent on him. (...) I could not make up my mind whether I wanted to tie my life to his. After 8 months, disgusted by myself, and under pressure from my mother I started to pressure him."

St. Petersburg inhabitants thus marry much more quickly than Finns after having had their first intercourse. This is related to both social conditions and cultural norms. In the Soviet Union, applying for an apartment and living together required that the couple was officially married. But also in other cases marriage was preferred over cohabitation, as the story of Elza's mother pressuring her showed.

Both the survey and the biographies show that there are stricter cultural norms in St. Petersburg than in Finland in regard to premarital sexual relations. In St. Petersburg both women's and men's attitudes towards sexual relations before marriage are more traditional or non-permissive than in Finnish cities in 1992 (see Figure 4). The values in St. Petersburg are closer to those in Finland in 1971 than 1992. In St. Petersburg men are at present even more traditional, and women as traditional, as Finns were in 1971. In St. Petersburg the restriction of sexual intercourse to marriage is thus evident both in the timing of sexual initiation and marriage and in people's attitudes.

Figure 4. Traditional attitudes towards premarital sexual relationships.

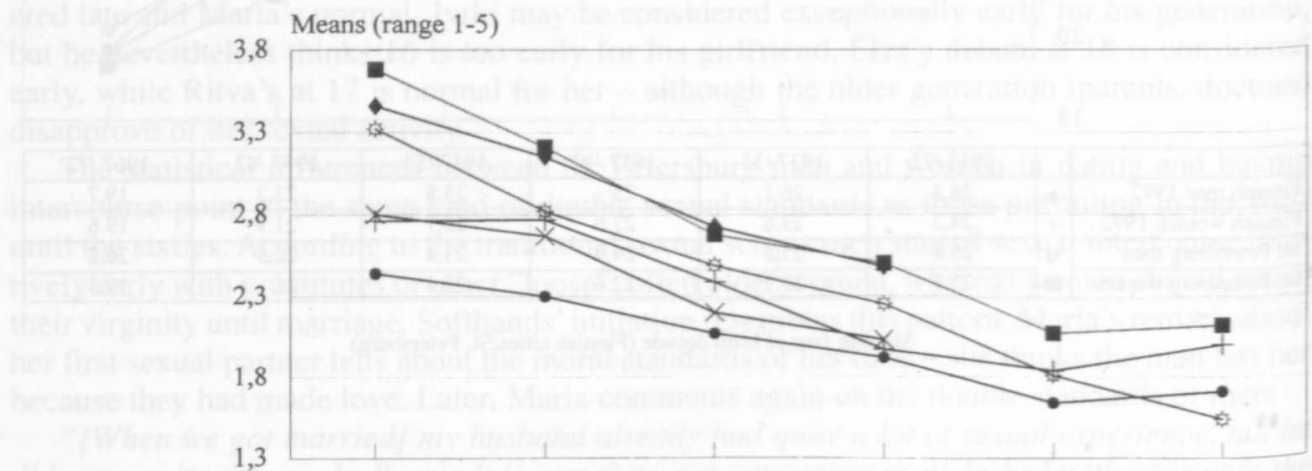

\begin{tabular}{|c|c|c|c|c|c|c|c|}
\hline & & $1917 / 22$ & $1927 / 32$ & $1937 / 42$ & $1947 / 52$ & $1957 / 62$ & $1967 / 72$ \\
\hline Finnish men 1992 & $\bullet$ & 2.4 & 2.3 & 2.1 & 1.9 & 1.6 & 1.7 \\
\hline Finnish women 1992 & + & 2.8 & 2.8 & 2.4 & 2 & 1.8 & 2 \\
\hline St. Petersburg men & $\Rightarrow$ & 3.3 & 2.8 & 2.5 & 2.3 & 1.8 & 1.5 \\
\hline St. Petersburg women & 룰 & 3.7 & 3.2 & 2.7 & 2.5 & 2.1 & 2.1 \\
\hline Finnish men 1971 & * & 2.8 & 2.7 & 2.2 & 2 & & \\
\hline Finnish women 1971 & $\downarrow$ & 3.5 & 3.2 & 2.7 & 2.5 & & \\
\hline
\end{tabular}

Starting year of birth decade (Finnish cities/St. Petersburg)

Question: When do you think it is appropriate for young people to have sexual intercourse?

When they 1 = have dated a few times, 2 = are going steady, 3 = are going steady and plannig to get married, $4=$ are engaged, $5=$ only when they are married. 
The time to "play around" - being sexually active without the commitment of a shared household - is nowadays equal for both sexes in Finland. In the generation of sexual repression, at first marriage men are two years older than women, in the generation of sexual revolution one year older, but there is no gender gap in the generation of sexual equalization. In St. Petersburg, the gender gap - men being older - at age of first marriage is two years in the older and middle generations and one year in the younger generation. Several Finnish autobiographies were written by young urban women who led an active and sexually experimenting life before settling down in their early thirties (Kontula and Haavio-Mannila 1995b).

Ritva is an excellent example of this. She has several shorter or longer sexual affairs, some based on love and some on friendship. At 24 she meets her future husband at her workplace, and they marry when she is 27 . She describes 13 happy years of marriage:

"I have retrospectively understood what kind of man I want and most of all - what I DON'T want. The main reason that those relationships collapsed were not in the sexual relationship, if by that you mean making love, but in a larger sense of the word-the cooperation of men and women in everyday life."

This kind of social group was less represented in the biographies from St. Petersburg (Rotkirch 1997). The women who married late or did not marry also usually started sexual life in their late twenties or early thirties. For men - as in the case of Softhands - the "experimenting" period was more usual. This picture is now confirmed by the survey data, which shows that St. Petersburg women in average have a relatively short sexually active period before marriage. Soviet women also have their first child sooner than Finnish women, and are in this respect more quickly tied to family life. This of course does not always prevent them from "experimenting" while being married, as the high proportion of people with extramarital affairs in St. Petersburg will show below.

Social class or education is strongly connected to delaying sexual initiation: people with more education start dating, having intercourse, and getting married later than those with less education, both in St. Petersburg and in Finland (Table 4). The early start of sexual life among less educated people has been found in several Finnish studies (e.g. Kontula 1991). Also according to several US studies, dropping out of school correlates with a young age of first sexual intercourse (Dorius et al. 1993). It is, however, hard to determine the causal chains between education and sexual life. Jyrki is, of course, an example of this, as are several other agrarian and working class biographies from both countries not referred to here.

Elza has a striking story about the different scripts for different social classes. At 15, she dates a boy who is two years older and "not a match", as her panicking parents tell her.

"I would really have wanted physical caresses, petting, and no 'pioneer [scout] relations' with him. But I was not going to be real close [have sex], and he understood that you can't do that with me after, it seems to me, having had a discussion with my father. He told me honestly that he wanted only to be close, and as I'd have to study, it is better for me not to be in touch with him, as it might end badly. (...) I was suffering from this forced separation. Everything was decided for me: what is good for me, and what is bad."

Her boyfriend and her father - if not Elza herself - seem to agree that a woman oriented on higher education should not be sexually active early. 
Table 4. Influence of education ${ }^{1}$ and age on sexual life in St. Petersburg in 1996 and Finnish cities in 1992: beta coefficients in regression analysis and their statistical significance.

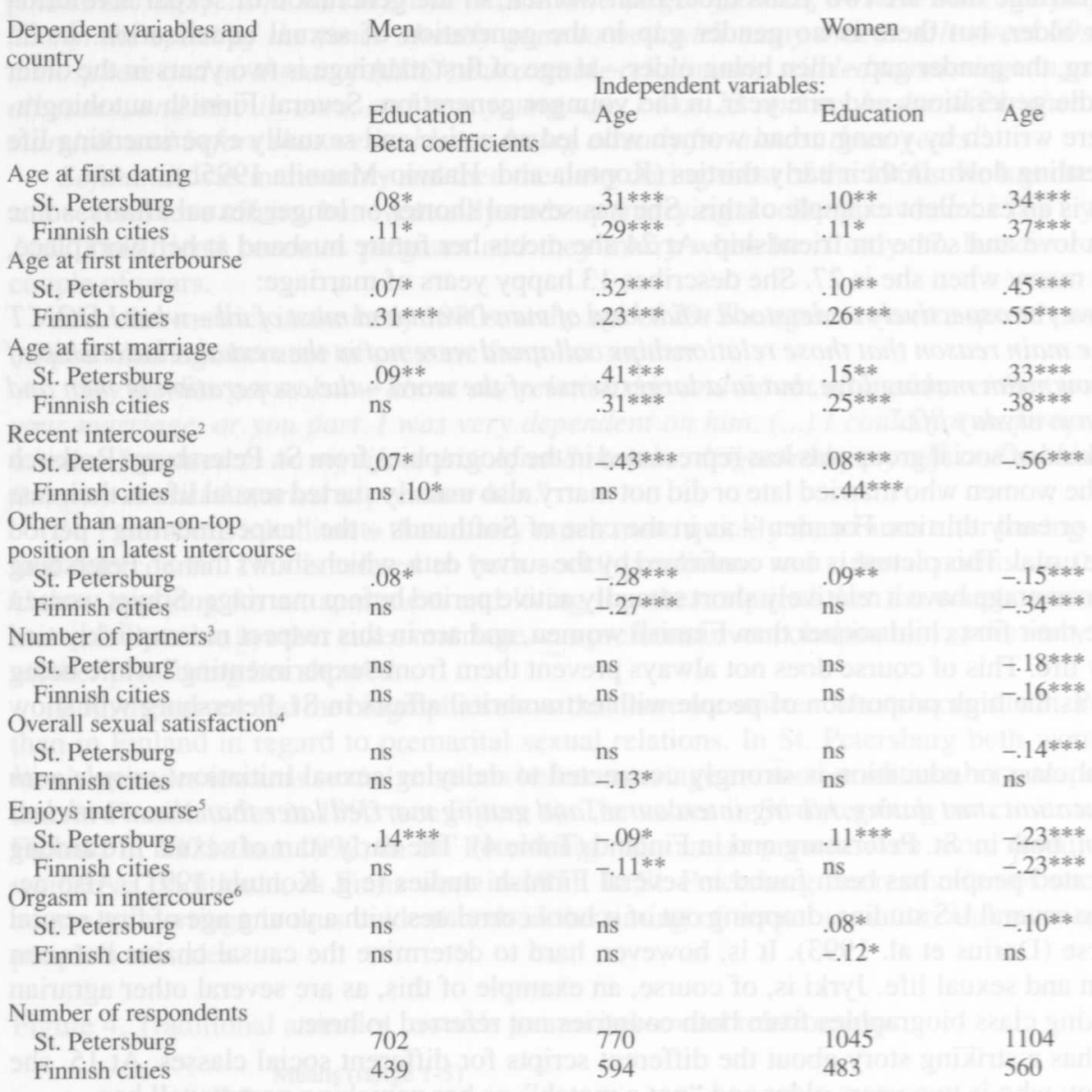

1) In Finland, social status is measured by the total number of years at school, both in general and vocational education. In St. Petersburg, the number of years at school was asked only for general education, not including years of vocational education. We have studied the effect of education on sexual life in St. Petersburg using both the number of years in general education and the level of vocational education as explanatory variables. The latter variable brought statistically "stronger" results, especially for men. The results in Table 3 are thus based on the level of vocational education, even though it is not an interval but only an ordinal scale. We use the following eight categories as parameters of the level of education: $0=$ no vocational education, $1=$ a course $(-6$ months $), 2=a$ course $(6-24$ months $), 3=$ lower certificate of vocational secondary education, $4=$ upper certificate of vocational secondary education, $5=$ uncompleted university degree, $6=$ university degree, and $7=$ researcher training. The correlation (r) between the number of years of general education and the above-mentioned level of occupational education is $.31 * * *$.

${ }^{2}$ Question: When was the last time that you had sexual intercourse? $1=$ over 10 years ago, $2=3-10$ years ago, $3=1-2$ years ago, $4=4-12$ years ago, $5=1-3$ months ago, $6=3-4$ weeks ago, $7=1-2$ weeks ago, $8=5-7$ days ago, $9=3-4$ days ago, $10=1-2$ days ago, and $11=$ during the last 24 hours.

3) More than 100 partners has been coded as 100 .

4) Question: If you evaluate your sexual life as a whole, would you say it has been $1=$ very unsatisfying, $2=$ quite unsatisfying, $3=$ neither satisfying nor unsatisfying, $4=$ quite satisfying, and $5=$ very satisfying.

5) Question: Have your experiences of sexual intercourse mostly been ....? 1 = very unpleasant, $2=$ quite unpleasant, $3=$ neither pleasurable nor unpleasant, $4=$ quite pleasurable, and $5=$ very pleasurable.

${ }^{6}$ Question: The culmination of sexual tension ending in a release and a feeling of pleasure is called orgasm. Have you had an orgasm during sexual intercourse? $1=$ never or seldom, $2=$ quite seldom, $3=$ about every other time, $4=$ almost always or usually, and $5=$ always. 


\section{Sexual practices}

Three indicators of sexual practices will be examined: length of time since the latest sexual intercourse, using some other position than lying down face-to-face, man on top and woman underneath in the latest intercourse and practicing oral sex on the partner. According to these criteria, sexual life in St. Petersburg is in some respects more traditional than in Finland, but there are also counter tendencies.

\section{Recent intercourse}

The frequency of sexual intercourse is measured here by the proportion of people having had their latest intercourse during the last two days. It is somewhat higher in Finland ( Table 5, $\left.\mathrm{F}=29.4^{* * *}\right)$. In both countries, men report more recent intercourse than women do $(\mathrm{F}=107.0 * * *)$. The gender gap in St. Petersburg is smaller than in Finland, particularly in the older generation, in which St. Petersburg men have intercourse less often than Finnish men do. The generational differences are large $(\mathrm{F}=214.4 * * *)$, particularly in Russia.

Table 5. Sexual practices: latest intercourse within last two days using other than man-on-top position in latest intercourse and having performed oral sex on partner during the last five years, percent.

\begin{tabular}{|c|c|c|c|c|c|c|}
\hline Year of birth & $\begin{array}{l}\text { St. } \\
\text { Petersburg } \\
\text { men }\end{array}$ & $\begin{array}{l}\text { St. } \\
\text { Petersburg } \\
\text { women }\end{array}$ & $\begin{array}{l}\text { Finnish city } \\
\text { men } 1992\end{array}$ & $\begin{array}{l}\text { Finnish city } \\
\text { women } \\
1992\end{array}$ & $\begin{array}{l}\text { Finnish city } \\
\text { men } 1971\end{array}$ & $\begin{array}{l}\text { Finnish city } \\
\text { women } \\
1971\end{array}$ \\
\hline \multicolumn{7}{|c|}{$\begin{array}{l}\text { Intercourse during } \\
\text { last two days }\end{array}$} \\
\hline $1917 / 22$ & 6 & 2 & 15 & 3 & 38 & 16 \\
\hline $1927 / 32-$ & 19 & 6 & 42 & 10 & 40 & 28 \\
\hline $1937 / 42-$ & 39 & 24 & 39 & 39 & 61 & 35 \\
\hline $1947 / 52-$ & 47 & 38 & 54 & 43 & 42 & 42 \\
\hline $1957 / 62-$ & 58 & 46 & 53 & 41 & & . \\
\hline $1967 / 72-$ & 34 & 42 & 34 & 39 & . & \\
\hline Total & 39 & 29 & 48 & 33 & 47 & 33 \\
\hline
\end{tabular}

Total significance $\mathrm{F}=$ country $29.4^{* * *}$, gender $107.0^{* * * *}$, cohort $214.4^{* * * *}$

Other than man-on-top

position

$\begin{array}{lllllll}1917 / 22- & 21 & 26 & 30 & 26 & 28 & 32 \\ 1927 / 32- & 29 & 33 & 41 & 28 & 24 & 28 \\ 1937 / 42- & 40 & 33 & 51 & 40 & 31 & 39 \\ 1947 / 52- & 56 & 54 & 51 & 52 & 34 & 34 \\ 1957 / 62- & 73 & 65 & 61 & 62 & . & . \\ 1967 / 72- & 72 & 74 & 60 & 45 & 30 & 34 \\ \text { Total } & 54 & 50 & 53 & \end{array}$

Total significance $\mathrm{F}=$ country $2.8 \mathrm{~ns}$, gender $4.1^{*}$, cohort $42.4^{* * *}$

Oral sex on

partner

$1927 / 32$

$1937 / 42-$

$1947 / 52-$

$1957 / 62$

$1967 / 72-$

Total

32
27
40 $\quad 15$

$\begin{array}{rrr}7 & 56 & 19 \\ 15 & 51 & 24 \\ 29 & 79 & 58 \\ 52 & 90 & 76 \\ 75 & 96 & 94 \\ 67 & 86 & 85 \\ 45 & 84 & 70 \\ 0^{* * *}, \text { gender } 45.2^{* * * *}, \text { cohort } 146.6^{* * * *}\end{array}$


The sexual life of the young is generally more active than that of the elderly. This can be seen when comparing the same birth cohorts of Finns interviewed in 1971 and 1992. In the generation of sexual repression, one-fourth of the women interviewed in 1971 reported having had sexual intercourse within a couple of days at the age of 35-54 years; the proportion was only seven percent in 1992, when these women were 55-74 years old. For men, the clearest decline in the frequency of sexual life has taken place in the oldest birth cohort, born in 19171926. In 1971, in this cohort, as many as 38 percent of the men had had intercourse during the last two days when they were 45-54 years old, but in 1992, only 15 percent had had intercourse as recently when they were 65-74 years old. The decline in the frequency of sexual activity with age is related to loss of sexual partners and decrease in sexual desire when people get older.

\section{Position in intercourse}

Using other than man-on-top ("missionary") positions in intercourse has been found to bring high sexual satisfaction (Darling et al. 1996; Haavio-Mannila and Kontula 1997). This proved to be about as common in St. Petersburg as in the Finnish cities, with the Russians clearly leading in the youngest generation. Generally, younger people use non-missionary position in sexual intercourse much more often than older people. This practice increases linearly from the oldest to the youngest birth cohort in both countries ( $\mathrm{F}$ for cohort difference is $42.4 * * *$ ). The rise in having intercourse in various positions took place in St. Petersburg 10-15 years later than in Finland, where the biggest change came with the birth cohort of 1937-1946, but in Russia first with the cohort born in 1962-1971. The generational dynamics are more dramatic in St. Petersburg, which was first below the Finnish average, and afterwards above. Could this be a consequence of the sexual revolution in the Russian media in recent years?

In Finland using other positions than man-on-top was already almost as common in 1971 as nowadays. Men report having used other than missionary position in their latest intercourse a little more often than women do $\left(\mathrm{F}=4.1^{*}\right)$.

Education has a different influence on sexual behavior in the two countries. In St. Petersburg, but not in Finland, the more educated people have had sexual intercourse more recently and more often used non-missionary positions in their latest intercourse than the less educated ones. In St. Petersburg, the higher status people are thus sexually quite active and use plural forms of sex. This can be explained by the relatively homogenous culture in Finland, and the public and mass nature of sexual enlightenment and other information. In Soviet Russia, by contrast, different classes and social milieus had different access to sexual information, e.g. in the form of Western literature. In the St. Petersburg biographies, women and men told of developing their sexual techniques on the basis of random but socially conditioned informal access to sources of sexual advice that were scarce until the 1990s. Softhands' parents "forgot" to hide a book about child development when he was in his early teens - these kinds of books were otherwise almost impossible to obtain for a young man. Maria tells us she read about female orgasm in 1984 but does not state where. Elza, as we have seen, got information from her girlfriends in her late teens, and not very accurate information at that: after her first intercourse she still does not know what sperm is.

\section{Oral sex}

Sexual stimulation of the partner by mouth, so-called "active" oral sex, has been tried at least once during the last five years by 84 percent of urban Finnish men and 70 percent of the women. In St. Petersburg the percentages are lower, 60 and 45 percent. In both countries, this sexual practice is very rarely used in the older generation, and in St. Petersburg also in the older part of the middle generation, in the cohort born in 1942-1951. 
The gender gap in engaging in oral sex with one's partner declines in both countries from the older to the younger generation in which it is almost non-existent. The country gap is highest in the cohort born in Finland in 1937-1946 and in Russia in 1942-1951, i.e. the older part of the generation of the Finnish sexual revolution. In that generation the sexual practices became liberated more quickly in Finland than in St. Petersburg. But also in the younger generations Finns engage more often in oral sex.

Oral sex is mentioned in only two of the six biographies studied here. Jyrki states he started practicing it quite late, but anyway with his own, first wife. Maria is sexually unsatisfied with her husband, and has several other affairs until she eventually divorces him. In her late thirties she finally meets her grand passion, with whom she also practices and enjoys oral sex for the first time.

\section{Sexual partners}

In this section we discuss the number and type of sexual partners in St. Petersburg and Finland. They are described by using three indicators: number of marriages or cohabitations, i.e. consecutive relations, having had extramarital or parallel sexual relations, i.e. complementary relations, and the number of sexual partners during one's lifetime, i.e. the quantity of sexual relationships.

\section{Consecutive marriages}

In the Finnish sexual autobiographies, women more often tell about consecutive loves, whereas men write about complementary affairs (Haavio-Mannila and Roos 1998; Kontula and Haavio-Mannila 1997a). According to survey data, women have been married or cohabited several times slightly more often than men: in St. Petersburg 21 percent of the women and 20 percent of the men, in the Finnish cities, 18 and 17 percent, respectively have married at least twice (Figure 5). The gender gap is not significant, but the country difference is $\left(\mathrm{F}=5.5^{*}\right)$, when birth cohort has been controlled. In 1971, there were very few remarried people in Finland. This finding is in accordance to divorce and remarriage statistics.

Figure 5. Several marriages or cohabitation.

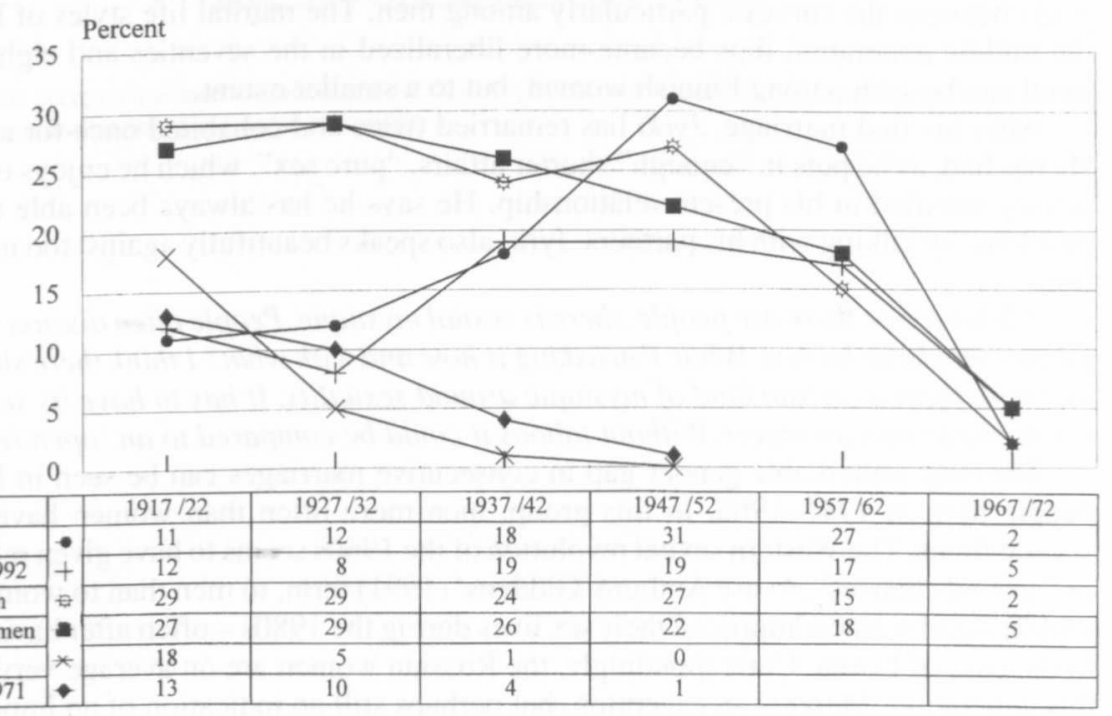

Starting year of birth decade (Finnish cities/St. Petersburg)

Base: total sample including persons who have never cohabited. 
Maria divorced her first husband soon after the birth of their first child. She then falls deeply in love and marries her second husband. They follow a vicious circle of unwanted pregnancies and abortions, as no available contraceptives work (when she gets an IUD in the 1970s, this problem stops). One of the pregnancies leads to the birth of her second child. She eventually initiates the divorce as she does not feel appreciated at home and has stopped loving him. "My days passed taking care of him, the children, we had no money, we started fighting and blaming each other. (...) I felt like a worn-out nag. (...) He couldn't understand why [I wanted a divorce]." She mentions lack of money, but not as a reason for separating. The third time she is also the one who ends a long relationship: she has been cohabiting with a man, her great sexual passion, for several years. But he drinks too much, does not want to separate legally from his former wife, and comes originally from a lower social class. At the time of finishing her biography, she is seeing a respectable and well-to-do man, whom she thinks of as at least a potential husband.

Softhands does not divorce and ends his story at the time when his married life has just begun. He describes it as "devoid of interest".

Leena, like Maria, meets her great sexual passion in her late thirties. She leaves her husband but the man she has fallen in love with does not get a divorce. The relationship continues for several years and they are still good friends. She continues a sexually active life, choosing her lovers, using pornography when she does not have a partner, but is not seeing anyone at the moment.

The generational dynamics in the frequency of having consecutive marital relations are very different in the two countries: almost thirty percent of the older generation of people in St. Petersburg have had several marriages, and the proportion slowly drops for the next generation. In Finland, the rate is, on the contrary, growing from about ten percent in the generation of sexual repression to almost double in the generation of sexual revolution. The result is congruent with the official statistics, showing the higher divorce rates in the former Soviet Union compared to Finland. The differences require more extensive analysis than what is possible here. The higher Russian figures are probably due to more extensive human losses during the Second World War, the earlier economic independence of Soviet women, the more liberal divorce legislation of the Soviet Union until 1944, and the more difficult material conditions in family life that strain the relationship between the partners (Haavio-Mannila and Kauppinen 1994; Liljeström 1995). In this indicator of sexual life, the effect of the 1917 October Revolution, including the sexual revolution that accompanied it in the beginning, is clearly seen.

"Serial polygamy" was rare among Finns interviewed in 1971. In the generation of sexual repression, the proportion of people with multiple marriages stayed the same until 1992. But in the Finnish generation of sexual revolution remarriages greatly increased during the twenty years between the surveys, particularly among men. The marital life styles of Finnish men of the middle generation thus became more liberalized in the seventies and eighties. The same trend can be seen among Finnish women, but to a smaller extent.

After his first marriage, Jyrki has remarried twice and cohabited once for a longer period. He has had, as he puts it, "enough" shorter affairs, "pure sex", which he enjoys enormously. He is very satisfied in his present relationship. He says he has always been able to solve sexual problems by talking with his partners. Jyrki also speaks beautifully against too much liberalization:

"Where ever there are people, there is sexual mystique. People often discuss whether sexual taboos should be broken. What I' $m$ asking is how and with what? I think there should be taboos and with them a certain kind of mystique around sexuality. It has to have its secrets, it should not be made into an object. Without taboos it could be compared to an 'open recipe book'!"

The only remarkable gender gap in consecutive marriages can be seen in Finland among people born in 1947-1966. In this group, men more often than women have been married several times. The Western sexual revolution of the 1960 s seems to have given more life choices or "second chances", to use Anthony Giddens' (1991) term, to men than to women. In Finland, middle-aged women improved their sex lives during the $1980 \mathrm{~s}$ - often after having divorced, as in the case of Leena. Correspondingly, the Russian women are on average very dissatisfied in this generation. Maria is an exception, but perhaps still an indication of an important trend, as we shall discuss below. 


\section{Attitudes towards infidelity}

With one exception, 20-27 percent of the people in St. Petersburg and Finnish cities accept the infidelity of a husband or a wife (Figure 6, Table 6). The only exception is the very permissive attitude toward the marital unfaithfulness of a husband among St. Petersburg men - accepted by every second man - and their non-permissiveness toward the infidelity of a wife accepted by only 17 percent. In Finland, the older generations conformed to the double standard by accepting a man's infidelity more easily. But by now, young Finnish men think the infidelity of a husband is less acceptable than that of a wife. Women from both countries have more understanding towards the infidelity of their own sex than men do. In Finland we can see both modernization and gender equalization; in Russia there is liberalization but only for the male sex, and no gender equalization at all!

Figure 6. Acceptance of infidelity of a husband.

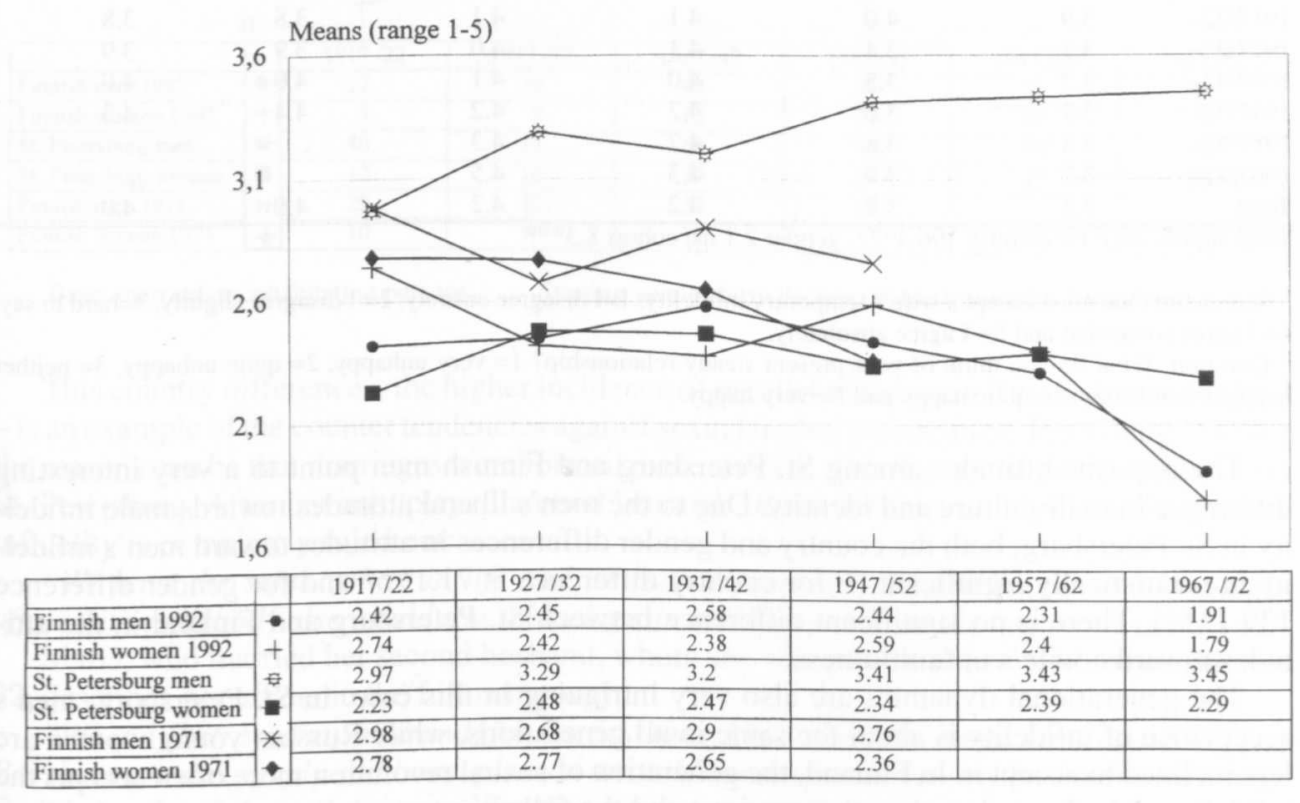

Starting year of birth decade (Finnish cities/St. Petersburg)

Statement: One must accept a husband's temporary infidelity. 1 = 1 disagree entirely, 2 = 1 disagree slightly, $3=$ hard to say, $4=1$ agree somewhat, and 5=1 agree absolutely. 
Table 6. Acceptance of a wife's infidelity and happiness of the present steady relationship, means, range $1-5$.

\begin{tabular}{lllllll} 
Year of birth & $\begin{array}{l}\text { St. } \\
\text { Petersburg } \\
\text { men }\end{array}$ & $\begin{array}{l}\text { St. } \\
\text { Petersburg } \\
\text { women }\end{array}$ & $\begin{array}{l}\text { Finnish city } \\
\text { men } \\
1992\end{array}$ & $\begin{array}{l}\text { Finnish city } \\
\text { women } \\
1992\end{array}$ & $\begin{array}{l}\text { Finnish city } \\
\text { men } \\
1971\end{array}$ & $\begin{array}{l}\text { Finnish city } \\
\text { women } \\
1971\end{array}$ \\
$\begin{array}{l}\text { Wife's infidelity' } \\
1917 / 22-\end{array}$ & 1.8 & 2.3 & 2.2 & & & \\
$1927 / 32-$ & 2.0 & 2.4 & 2.5 & 2.6 & 2.9 & 2.7 \\
$1937 / 42-$ & 2.2 & 2.7 & 2.7 & 2.5 & 2.6 & 2.7 \\
$1947 / 52-$ & 2.0 & 2.5 & 2.5 & 2.7 & 2.6 & 2.5 \\
$1957 / 62-$ & 2.2 & 2.5 & 2.4 & 2.5 & 2.5 & 2.3 \\
$1967 / 72-$ & 2.3 & 2.4 & 2.0 & 1.8 & 2. & \\
Total & 2.1 & 2.5 & 2.4 & 2.4 & 2.7 & 2.6 \\
\hline
\end{tabular}

Total significance $\mathrm{F}=$ country $2.0 \mathrm{~ns}$, gender $23.9^{* * *}$, cohort $4.1^{* * *}$

\begin{tabular}{lllllll}
$\begin{array}{l}\text { Happy steady } \\
\text { relationship }\end{array}$ & & & & & & \\
$1917 / 22-$ & 3.9 & 4.0 & 4.1 & 4.1 & 3.8 & 3.8 \\
$1927 / 32-$ & 3.7 & 3.4 & 4.1 & 4.0 & 3.9 & 3.9 \\
$1937 / 42-$ & 3.7 & 3.5 & 4.0 & 4.1 & 4.0 & 4.0 \\
$1947 / 52-$ & 3.7 & 3.6 & 4.2 & 4.2 & 4.4 & 4.3 \\
$1957 / 62-$ & 3.8 & 3.8 & 4.2 & 4.3 &. &. \\
$1967 / 72-$ & 3.7 & 3.9 & 4.3 & 4.5 & & \\
Total & 3.8 & 3.7 & 4.2 & 4.2 & 4.0 & 4.0 \\
\hline
\end{tabular}

Total significance $\mathrm{F}=$ country $196.4^{* * * *}$, gender $2.1 \mathrm{~ns}$, cohort $8.3^{* * *}$

1) Statement: One must accept a wife's temporary infidelity. I=I disagree entirely, 2=I disagree slightly, $3=$ hard to say, 4= I agree somewhat and 5= I agree absolutely.

${ }^{2}$ Question: What do you think of your present steady relationship? 1= very unhappy, 2= quite unhappy, 3= neither happy nor unhappy, $4=$ quite happy and $5=$ very happy.

The opposite attitudes among St. Petersburg and Finnish men point to a very interesting difference in male culture and identity. Due to the men's liberal attitudes towards male infidelity in St. Petersburg, both the country and gender differences in attitudes toward men's infidelity are statistically significant ( $\mathrm{F}$ for country difference is $71.1 * * *$ and for gender difference $\left.139.1^{* * *}\right)$. There is no significant difference between St. Petersburg and Finland in the attitudes toward a wife's unfaithfulness.

The generational dynamics are also very intriguing in this case. In St. Petersburg, men's acceptance of infidelity is about the same in all generations, while Russian young women are less inclined to accept it. In Finland, the generation of sexual revolution more often accepts the infidelity of both genders than the previous and the following generations. It is remarkable to notice that the young Finnish people belonging to the generation of sexual revolution interviewed in 1971 were more permissive than young people of the generation of sexual ambivalence are today. While the Finnish pattern can be interpreted as moving from traditionalism to liberalization and then to neo-traditionalism, the Russian attitudes do not follow the same pattern or even parameters. One of them is growing polarization between men's and women's attitudes: in St. Petersburg, the gender differences in the attitude toward a husband's infidelity among young people are larger than among the older ones. Young Russian men are very permissive and young women very restrictive as regards men's unfaithfulness.

\section{Extramarital relations}

Extramarital or parallel sexual relationships in the present relationship are reported more often in St. Petersburg than in Finland (Figure 7). Fifty-two percent of the Petersburg men and 41 percent of the Finnish men, and 24 percent and 15 percent of the women, respectively, had had intercourse with someone other than one's steady partner while living in their present couple relationship. Still, the gender gap is much larger $(\mathrm{F}=185.3 * * *)$ than the country gap $(\mathrm{F}=$ $\left.20.6^{* * *}\right)$. 
Figure 7. Parallel sexual relationships during present marriage or cohabitation.

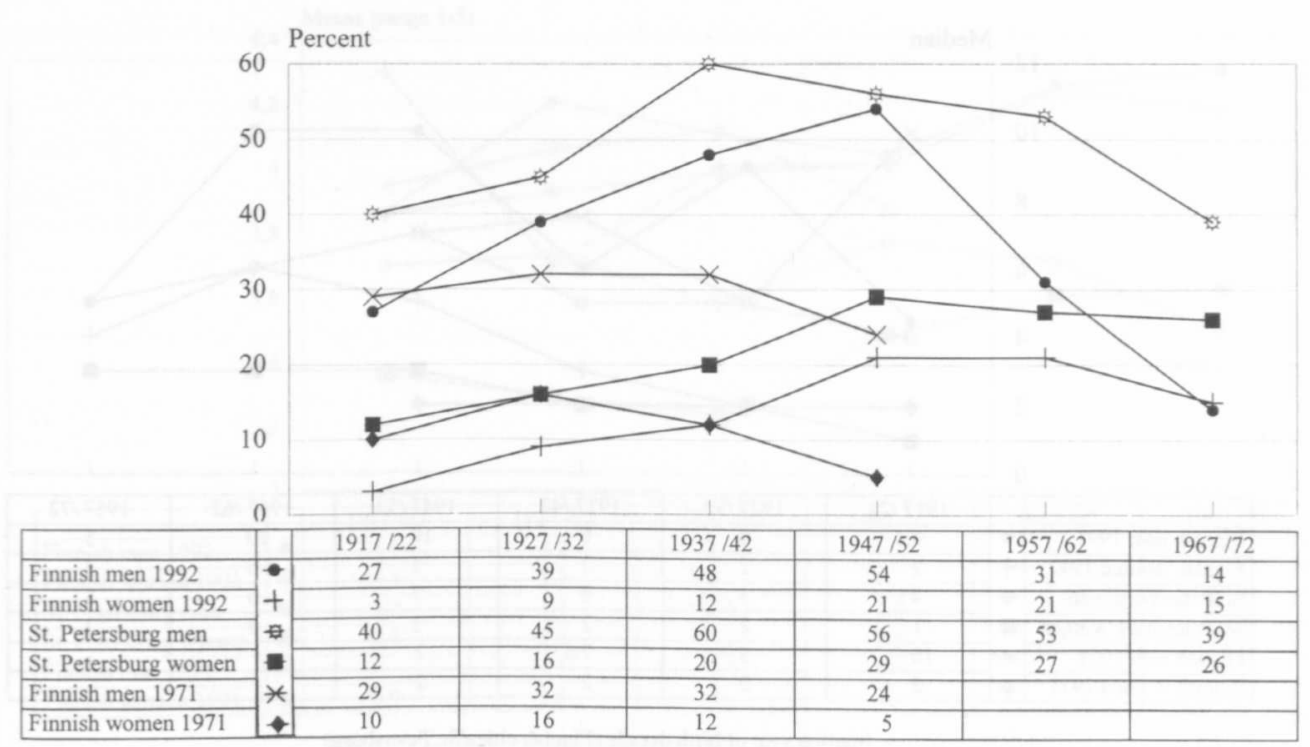

Base: married or cohabitating persons. Starting year of birth decade (Finnish cities/St. Petersburg)

This country difference - the higher incidence of parallel relations in Russia than in Finland - is an example of the counter tendencies against sexual traditionalism in St. Petersburg. Among the reasons can be that marriages were formed more quickly after the sexual debut (cf above) in St. Petersburg. After having "played around" enough, Ritva presents an idyllic ending where infidelity is completely ruled out:

"We have the same values in life and we both disapprove of infidelity. Even a one-night affair with somebody else would sow a black grain and that would be the beginning of the end."

Maria, who married her second husband, whom she was greatly in love with when she was 22 , describes her affairs in the following way:

"When I [betrayed my husband] for the first time, I had a violent shock. How could I?!! (...) But this man was simply stubborn, pleased me, told me tender things (my husband - no way!). So I surrendered. Later I did not suffer that much anymore."

The gender gap in having had extramarital relations is most pronounced in Finland in the whole generation of sexual revolution and in Petersburg in the older part of the middle generation (born in 1942-1951). In both countries, the men of the middle generations report exceptionally many extramarital affairs, while the infidelity of women has risen slowly but more steadily.

\section{Number of sexual partners}

While more people in St. Petersburg have consecutive and complementary sexual relations, the mean and median number of lifetime sexual partners (Figure 8) is lower than among Finns $(\mathrm{F}=16.7 * * *$ when the effect of gender and birth cohort has been controlled). The median number of partners for Finnish men is ten and for Finnish women four, for St. Petersburg five and three, respectively. The gender gap in the mean number of lifetime sexual partners is larger than the country gap $(\mathrm{F}=107.2 * * *)$. 
Figure 8. Median number of sexual partners during lifetime.

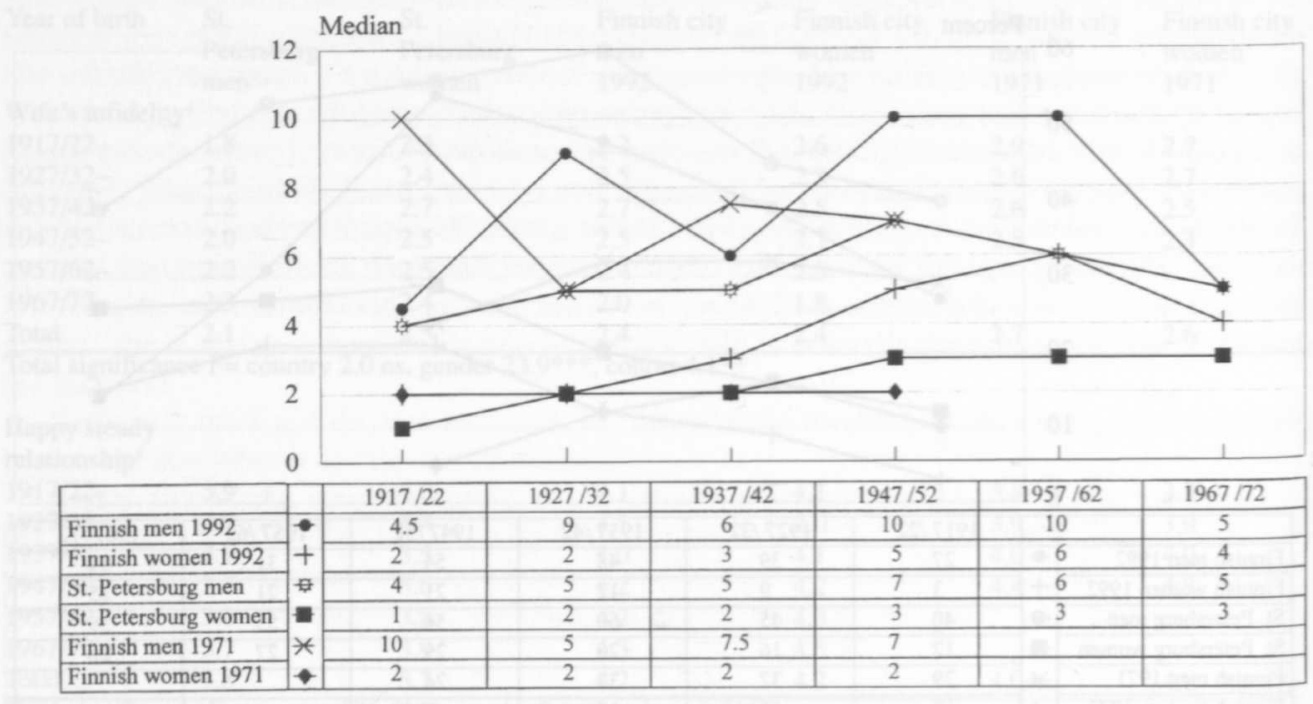

Starting year of birth decade (Finnish cities/St. Petersburg)

Base: respondents with sexual partners.

This country discrepancy in the sexual pluralism measured by the three different indicators - several marriages and parallel relations vs. number of partners - is due to the large number of partners of Finns with consecutive and/or complementary relations or not cohabiting (HaavioMannila 1997). In St. Petersburg many people have several partners but the number is more moderate than in Finland, where there is a small group of "sexual addicts".

This result contradicts the widespread opinion that the St. Petersburg urban society would have been very "loose" or promiscuous during late socialism. On the other hand, class differences are important in this respect. There seem to have been certain promiscuous milieus, coexisting with traditional and restricted sexual behavior (Rotkirch 1997). Education is not linearly connected to the number of partners during one's lifetime. In St. Petersburg women with middle level education, i.e. a lower certificate of vocational education, have the largest number of partners, $4.9(\mathrm{~N}=239$; the average being 4.1). The lower number of partners among Russian women with more education can be due to the influence of certain more educated, Westernized milieus, as discussed above in the chapter on positions in intercourse. Russian men with a university education $(\mathrm{N}=282$ ) have had more partners than other men, on the average 13.3 (all men 12.1). Finnish men and women with college or university level education have had slightly more partners than the less educated ones.

\section{Sexual satisfaction}

Above we have studied sexual behavior patterns, i.e. sexual initiation, practices and partners. In this final section, we examine sexual satisfaction on the basis of five indicators: overall sexual satisfaction, happiness of a steady relationship, experiencing coitus as pleasurable, achieving orgasm in intercourse, and a wish to have intercourse more frequently.

Satisfaction with sexual life as a whole is higher in Finland than in St. Petersburg (see Figure 9). The difference between the two countries is very large ( $\left.\mathrm{F}=179.2^{* * *}\right)$. The gender gap is smaller $\left(\mathrm{F}=24.8^{* * *}\right)$. 24). Men are more satisfied than women. 
Figure 9. Satisfaction with sexual life.

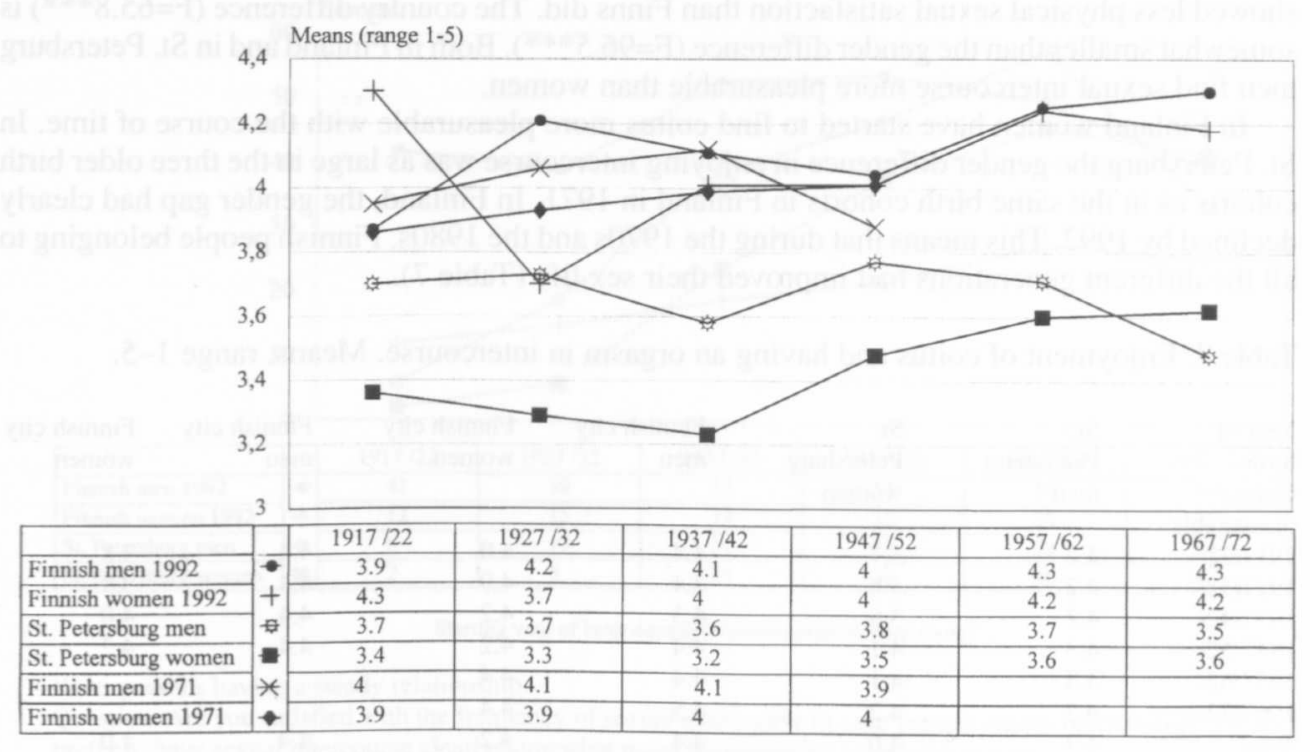

Starting year of birth decade (Finnish cities/St. Petersburg)

The gender difference in overall sexual satisfaction is very large in St. Petersburg compared with Finland. This is due to the fact that older and middle-aged St. Petersburg women are much less satisfied with their sexual life than St. Petersburg men of the same generations. Sexual satisfaction is not statistically significantly related to education either in St. Petersburg or in Finland (see Table 4 above).

Among women of the middle generation, the country difference in overall sexual satisfaction is very high: the middle-aged Russian women are much less satisfied than the respective Finnish women.

In the Russian biographies, there were several deeply dissatisfied stories we have not handled here. Often the husband is the woman's first and only sexual partner, who has sex when he is drunk and/or violent, or just indifferent towards her needs. One woman, born in 1936, ends her story by explaining that she nowadays "probably has given [her]self up as a woman". Another woman, born in 1946, thinks a psychoanalyst might be the only way out. The six biographies we have chosen to present here tell about great dissatisfaction at some life stages, but also about improvement of sexual life.

As already was mentioned, Maria learns how her body functions after reading in a book about female orgasm. It is 1984, some years before the liberalization of the press, but, of course, Western journals and underground texts were available in some metropolitan milieus. She then asks her lover (she is living alone at the time):

"Tell me, am I a normal woman? - No, you are a fantastic woman! After painful consideration I asked again: why don't I have the same, in the end, as you do? And he showed me in slow motion that I did."

Still, what Maria calls real sex - not "sex" in quotation marks - is something she experienced only in her third long relationship. For her, the difference was that she was used to pleasing men, while this man did everything to please her.

"I let him do everything I did not even want to hear about before. And, what was most important, I myself did it also. Before him I had never touched any man with so much as one finger, I tried to look away from a naked male body, as they seemed disgusting. But now I caressed and kissed his body myself and enjoyed it." 
Enjoyment of sexual intercourse was investigated by asking how pleasurable people's experiences of sexual intercourse mostly had been. The St. Petersburg respondents, especially women, showed less physical sexual satisfaction than Finns did. The country difference $\left(\mathrm{F}=65.8^{* * *}\right)$ is somewhat smaller than the gender difference ( $\left.\mathrm{F}=96.5^{* * *}\right)$. Both in Finland and in St. Petersburg men find sexual intercourse more pleasurable than women.

In Finland women have started to find coitus more pleasurable with the course of time. In St. Petersburg the gender difference in enjoying intercourse was as large in the three older birth cohorts as in the same birth cohorts in Finland in 1971. In Finland, the gender gap had clearly declined by 1992 . This means that during the 1970 s and the 1980 s, Finnish people belonging to all the different generations had improved their sex life (Table 7).

Table 7. Enjoyment of coitus and having an orgasm in intercourse. Means, range 1-5.

\begin{tabular}{|c|c|c|c|c|c|c|}
\hline $\begin{array}{l}\text { Year of } \\
\text { birth } \\
\text { Coitus } \\
\text { pleasurable }\end{array}$ & $\begin{array}{l}\text { St. } \\
\text { Petersburg } \\
\text { men }\end{array}$ & $\begin{array}{l}\text { St. } \\
\text { Petersburg } \\
\text { women }\end{array}$ & $\begin{array}{l}\text { Finnish city } \\
\text { men }\end{array}$ & $\begin{array}{l}\text { Finnish city } \\
\text { women }\end{array}$ & $\begin{array}{l}\text { Finnish city } \\
\text { men }\end{array}$ & $\begin{array}{l}\text { Finnish city } \\
\text { women }\end{array}$ \\
\hline $1917 / 22-$ & 4.2 & 3.7 & 4.4 & 4.0 & 4.4 & 3.8 \\
\hline $1927 / 32$ & 4.2 & 3.8 & 4.4 & 4.9 & 4.4 & 3.9 \\
\hline $1937 / 42$ & 4.2 & 3.8 & 4.3 & 4.2 & 4.4 & 4.0 \\
\hline $1947 / 52-$ & 4.3 & 4.1 & 4.4 & 4.2 & 4.4 & 4.2 \\
\hline $1957 / 62-$ & 4.3 & 4.1 & 4.4 & 4.4 & & \\
\hline $1967 / 72$ & 4.3 & 4.2 & 4.5 & 4.4 & & \\
\hline Total & 4.3 & 4.0 & 4.4 & 4.2 & 4.4 & 4.0 \\
\hline
\end{tabular}

Total significance $\mathrm{F}=$ country $65.8^{* * *}$, gender $96.5^{* * *}$, cohort $14.6^{* * *}$

\begin{tabular}{llllll} 
Orgasm & & & & & \\
$1917 / 22-$ & 4.2 & 2.5 & 4.0 & 3.2 & 3.9 \\
$1927 / 32-$ & 4.2 & 2.9 & 4.6 & 2.9 & 3.2 \\
$1937 / 42-$ & 4.4 & 2.9 & 4.5 & 2.3 & 3.0 \\
$1947 / 52-$ & 4.4 & 3.2 & 4.5 & 3.2 & 3.1 \\
$1957 / 62-$ & 4.3 & 3.3 & 4.5 & 3.2 & 3.1 \\
$1967 / 72-$ & 4.4 & 2.9 & 4.4 & 3.1 & 3.1 \\
Total & 3.3 & 3.0 & 4.5 & 3.1 & \\
\hline
\end{tabular}

Total significance $\mathrm{F}=$ country $7.2^{* *}$, gender $908.1^{* * *}$, cohort $6.3^{* * *}$

St. Petersburg people report somewhat less orgasm in intercourse, defined as the culmination of sexual tension ending in release and a feeling of pleasure, than Finns do. The country difference $\left(\mathrm{F}=7.2^{* *}\right)$ is much smaller than the huge gender gap $\left(\mathrm{F}=908.1^{* * *}\right)$ : men achieve orgasm in intercourse much more frequently than women do. Interestingly, the country gap in achieving orgasm is not so large as one could have expected on the basis of the other indicators of sexual satisfaction.

In the oldest cohort, the gender gap in orgasm is much larger in St. Petersburg than in Finland. Only 32 percent of St. Petersburg women of this age reported achieving orgasm always or almost always in intercourse, while 50 percent of the respective Finnish urban women did so.

Overall sexual satisfaction is not connected to social status. In St. Petersburg the better educated women enjoy intercourse and get an orgasm in intercourse more often than the less educated women. In the Finnish cities, those women who have spent many years at school, are not as orgastic in intercourse as those who have left school earlier (see Table 4 above).

Finnish men would prefer to have sexual intercourse in their present couple relationship much more often ( 49 percent) than Finnish women ( 22 percent). In St. Petersburg this gender gap is narrower: 45 percent of Russian men and 34 percent of the women would prefer more frequent intercourse. In the middle and younger generations, St. Petersburg women are much more eager to have more frequent intercourse than Finnish women are (Figure 10). The country difference is not statistically significant but the gender difference is $(\mathrm{F}=58.9 * * *)$. 
Figure 10. Prefers more frequent intercourse in present steady relationship.

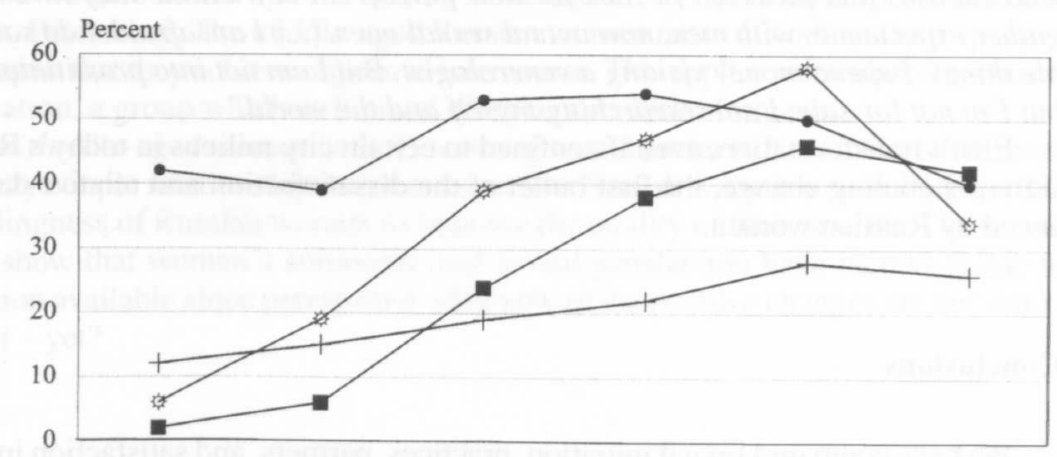

\begin{tabular}{|l|c|c|c|c|c|c|c|}
\hline & & $1917 / 22$ & $1927 / 32$ & $1937 / 42$ & $1947 / 52$ & $1957 / 62$ & $1967 / 72$ \\
\hline Finnish men 1992 & 42 & 39 & 53 & 54 & 50 & 40 \\
\hline Finnish women 1992 & 12 & 15 & 19 & 22 & 28 & 26 \\
\hline St. Petersburg men & 6 & 19 & 39 & 47 & 58 & 34 \\
\hline St. Petersburg women & & 6 & 6 & 24 & 38 & 46 & 42 \\
\cline { 3 - 8 } & & & & &
\end{tabular}

Starting year of birth decade (Finnish cities/St. Petersburg)

Base: persons having a steady relationship.

Question: Are you satisfied with the frequency of sexual intercourse in your present steady relationship? I would prefer to have sexual intercourse clearly/somewhat more frequently vs. as/less frequently.

In all St. Petersburg birth cohorts, the gender gap (men-women) in wanting to have intercourse more frequently is only about ten percentage points. In the youngest cohort, St. Petersburg women wish for even more frequent intercourse than St. Petersburg men do. In Finland, the gender gap is as high as 20 to 30 percentage points, except in the youngest cohort where it is only 14 points. In both countries, the youngest men do not wish for more frequent intercourse as often as middle-aged men do. They seem to get their sexual needs relatively well fulfilled in their couple relationships.

The wish of St. Petersburg middle-aged and younger women to have sexual intercourse more frequently may be related to their attempts to improve the quality of their sexual life. As already discussed above, St. Petersburg women are less satisfied with sexual life in general and enjoy intercourse less than Finnish women do. Their expression of dissatisfaction together with a wish for more frequent sex can be interpreted as "relative deprivation" - perhaps even increased dissatisfaction, brought about by the newly available sexual information. (This interpretation was suggested to us by Elena Zdravomyslova.)

Maria now has a steady partner, but no real sexual satisfaction:

"He once told me that he does not believe me, that nothing like that [passion] had happened to me, that he does not believe there are any men like those I say and that one can't do it any differently with me, that it would be the same for me with anyone else. (...) And once again SOMETHING is happening under the blanket in the dark, something, but only not sex."

Although she seems resigned, this ending of Maria's biography can also be read as clear motivation and readiness to change her life. But the most dramatic change is in Elza's sexual life. After having married her great sexual passion under pressure, she gives birth to three children. After the last one, she begins to enjoy motherhood, and develops a stronger and more confident personality. Sexual life with her husband is very bad, and her only relief is masturbation, which he strongly disapproves of. She has several painful abortions. But at the end of the 1980 s, when perestroika is in full bloom, she starts to change her life radically. She mentions active interest in both Eastern religions and Orthodoxy, psychotherapy and general spiritual growth. At that time, she has sex only with her husband. But during the last year she has begun to search for partners through advertisements. She has adequate contraception, she regularly visits a gynecologist to protect herself against venereal diseases, and she finally allows herself "to get to know life through love": 
"I get less and less romantic and more and more sober. I make my life myself. I am the one who chooses and picks. (...) I look for new partners. They tell me they love me. I continue to gather experiences with men, now actual sexual ones. (...) I am afraid. I do socially condemnable things. I spend money visiting a venerologist. But I am not into prostitution. I am choosing, but I' $m$ not for sale. I am researching myself and the world."

Elza's transformation, even if confined to certain city milieus in today's Russia, might be a sign of a coming change, the first outlet of the dissatisfaction and relative deprivation experienced by Russian women.

\section{Conclusions}

We have compared sexual initiation, practices, partners, and satisfaction in urban Finland in 1971 and 1992 and in St. Petersburg in 1996 on the basis of large representative survey data and sexual autobiographies. Even though St. Petersburg is a metropolis and some of the Finnish towns are quite small, we consider the comparisons feasible.

The gender roles in sexual life have equalized during the last decades in both countries. In many aspects of sexual behavior and satisfaction, young men and young women resemble each other much more than elderly men and women do, and than the Finnish men and women studied in 1971 did.

Compared to Finland, St. Petersburg shows more differentiation of gender roles. There are trends of a growing gender polarization during the transition of the $1990 \mathrm{~s}$. This is the case, for example, in attitudes towards infidelity in marriage. Young men are very liberal, whereas young women are very restrictive towards male unfaithfulness. St. Petersburg men afford men much more sexual freedom than women, which we interpret as a cultural inertia in abandoning the traditional double standards of sexual morality. Similar results are found in attitudes towards selling sexual services and casual sexual relationships in St. Petersburg (Gronow et al. 1996).

There is an approximately fifteen-year time gap in the liberalization of sexual life between Finnish cities and St. Petersburg. The impacts of sexual liberalization or revolution, which took place in Finland earlier, around 1970 and in St. Petersburg in the 1980 s, were clearly to be seen in some of our results. Generally, St. Petersburg people are more traditional than Finns. They start dating and having sexual intercourse later, but they marry at the same age as Finns do. Thus there is a shorter time of "playing around" before formal commitment to family life. This is related to the traditional attitudes toward premarital sex in St. Petersburg, and a preserved high cultural value of virginity that is described in the autobiographies. The conservatism in St. Petersburg could also be seen in the less versatile sexual techniques, for example, in not engaging in oral sex, in the lower frequency of intercourse especially in the older generation, and in the smaller number of lifetime sexual partners. On the average, Finns are sexually more satisfied, happier in their couple relationships, enjoy coitus more, and more frequently get orgasm in intercourse than people in St. Petersburg do.

But it is not true that all sexual patterns are more traditional in St. Petersburg than in Finland. St. Petersburg inhabitants have divorced and had extramarital relations more often than Finns. There is no country difference in using other than man-on-top position in sexual intercourse. In the biographies, there are some classical accounts of sexual liberation (women tell about doing things they had not even wanted to hear about before).

Our second hypothesis was that the sexual traditionalism before perestroika had especially influenced the sexuality of women. Again, this holds true in some but not all respects. The gender gap in the middle generation, which in Finland is called that of sexual revolution, is larger in St. Petersburg than in Finland. St. Petersburg women of the middle generation have delayed coitus and having started it, have quickly married. In mid-life they are dissatisfied with intercourse and their overall sexual life. As there was practically no sex education in their youth and they had difficult times with birth control, many have not learned how to enjoy sex. The middle-aged St. Petersburg women, for example, do not practice oral sex as much as women of the same generation in Finland (or the younger people in St. Petersburg) do. 
As it was not true that all kinds of sexual practices are more traditional in St. Petersburg than in Finland, so we also found that the quality of sexual life is not in all respects better in Finland than in St. Petersburg. The middle-aged Russian women more often than the respective Finnish women report that they achieve orgasm in intercourse. This applies particularly to women with higher education, a group which in Finland often reports lack of orgasm.

The young and middle-aged women in St. Petersburg would prefer to have intercourse more often in their steady couple relationship than the respective Finnish women would. Perhaps this indicates the willingness of Russian women to improve the quality of their sex life. The sexual autobiographies show that women's autonomy and sexual satisfaction have increased due to the new information available since perestroika, although all the positive changes are not statistically significant - yet?

\section{References}

Bertaux, Daniel. 1997. Les récits de vie. Paris: Nathan.

Darling, Carol, Elina Haavio-Mannila, and Osmo Kontula. Orgasmic frequency in Finland: do age and gender make a difference? Manuscript, June 1997.

Dorius, Guy L.,Tim B. Heaton, and Patrick Steffen. 1993. Adolescent life events and their association with the onset of sexual intercourse. Youth \& Society 25: 3-23.

Francoeur, Robert T. 1990. Becoming a sexual person. 2nd edition. New York: Macmillan.

Giddens, Anthony 1991. Modernity and self-identity: self and society in late modern age. Stanford, CA: Stanford University Press.

Gronow, Jukka, Elina Haavio-Mannila, Markku Kivinen, Markku Lonkila, and Anna Rotkirch. 1997. Cultural inertia and social change in Russia. University of Helsinki, Department of Sociology. (stencil).

Haavio-Mannila, Elina. 1997. Consecutive and parallel sexual relations in urban Finland and in St. Petersburg in Russia. Third European Conference for Sociology, University of Essex, August 26-30. Conference paper.

Haavio-Mannila, Elina and Kaisa Kauppinen. 1994. Changes in the status of women in Russia and Estonia. In: Change and continuity in Eastern Europe, edited by Timo Piirainen, pp. 173-203. Aldershot, Hampshire: Dartmouth.

Haavio-Mannila, Elina, J.P. Roos, and Osmo Kontula. 1996. Repression, revolution and ambivalence: the sexual life of three generations. Acta Sociologica 39(4):409-430.

Haavio-Mannila, Elina and Osmo Kontula. 1997. Correlates of sexual satisfaction. Archives of Sexual Behavior 26(4):399-419.

Haavio-Mannila, Elina and J.P. Roos. 1998. Love stories in sexual autobiographies. The narrative study of lives. Vol 5.

Kon, Igor S. 1995. The sexual revolution in Russia: from the age of the czars to today. New York: The Free Press.

Kontula, Osmo. 1991. Sukupuolielämän aloittamisen yhteiskunnallisista ehdoista (Cultural terms of sexual initiation). Tutkimuksia, No. 14. Helsinki: Sosiaali- ja terveyshallitus.

Kontula, Osmo and Elina Haavio-Mannila. 1993. Suomalainen seksi: tietoa suomalaisten sukupuolielämän muutoksesta (Finnish sex: information on the change of the sex life of the Finns). Helsinki-PorvooJuva: WSOY.

Kontula, Osmo, Elina Haavio-Mannila, and Helena Suoknuuti. 1994. Finnish sex: the tables of all the questions of the 1992 survey and the comparable questions of the 1971 survey. Kansanterveystieteen laitoksen julkaisuja M 113:1994. Helsinki: Yliopistopaino.

Kontula, Osmo and Elina Haavio-Mannila. 1995a. Sexual pleasures: enhancement of sex life in Finland, 1971-1992. Aldershot, Hampshire: Dartmouth.

Kontula, Osmo and Elina Haavio-Mannila. 1995b. Matkalla intohimoon (On the way to passion). HelsinkiPorvoo-Juva: WSOY.

Kontula, Osmo and Elina Haavio-Mannila. 1997a. Intohimon hetkiä (Moments of passion). PorvooHelsinki-Juva: WSOY.

Kontula, Osmo and Elina Haavio-Mannila. 1997b. Finland. In: The International Encyclopedia of Sexuality, Volume I, Argentina to Greece, edited by Robert T. Francoeur, pp. 419-491. New York: Continuum.

Kontula, Osmo and Kati Kosonen. 1994. Seksiä lehtien sivuilla (Sex on the pages of journals). Helsinki: Painatuskeskus.

Laumann, E.O., J.H. Cagnon, R.T Michael, and S. Michaels. 1994. The social organization of sexuality. sexual practices in the United States. Chicago: The University of Chicago Press.

Lennerhed, Lena. 1994. Frihet att njuta: sexualdebatten I Sverige på 1960-talet. Stockholm: Norstedts.

Lewin, Bo (ed.). 1997. Sex i Sverige: om sexuallivet I Sverige 1996 (Sex in Sweden: on the sex life in Sweden 1996). Uppsala: Uppsala Universitets Förlag. 
Liljeström, Marianne. 1995. Emanciperade till underordning: det sovjetiska könssystemets uppkomst och diskursiva reproduktion (Emancipated into resignation: the birth of the Soviet gender system and discursive reproduction). Åbo: Åbo Akademis förlag.

Menand, Louis. 1997. It's a wonderful life. The New York Review of Books, February 6, 25-29.

Rantalaiho, Liisa. 1994. Sukupuolisopimus ja Suomen malli (Gender contract and the Finnish model). In: Naisten hyvinvointivaltio, edited by Anneli Anttonen, Lea Henriksson, and Ritva Nätkin, pp. 9-30. Tampere: Vastapaino.

Rotkirch, Anna. 1997. What kind of sex can you talk about? Acquiring sexual knowledge in three Soviet generations. Third European Conference for Sociology, University of Essex, August 26-30. Conference paper.

Rotkirch, Anna and Elina Haavio-Mannila. 1997. The naming and processing of sexual violence in Russian and Estonian autobiographies. Baltic-Nordic Summer School on Sexual Issues. Valmiera, Latvia, August 1-5. Conference paper.

Semyonova, Viktoria. 1996. Ravenstvo v nishchete: simbolocheskoe znachenie "kommunalok" v 30-50e gody. In: Sudby liudei: Rossiia XX vek: biografii semei kak obekt sotsiologicheskogo issledovaniia, edited by Victoria Semyonova, Ekaterina Foteeva, and Daniel Bertaux, pp.373-389. Moscow: Institut sotsiologii RAN.

Sievers, Kai, Osmo Koskelainen, and Kimmo Leppo. 1974. Suomalaisten sukupuolielämä (The sexual life of Finns). Porvoo-Helsinki: WSOY

St. Petersburg - Helsinki - Turku in Figures. 1997. Helsinki: City of Helsinki Urban Facts.

Wellings, K., J. Field, A.M Johnson, and J. Wadsforth 1994. Sexual behaviour in Britain: a national survey of sexual attitudes and lifestyles. London: Penguin Books. 